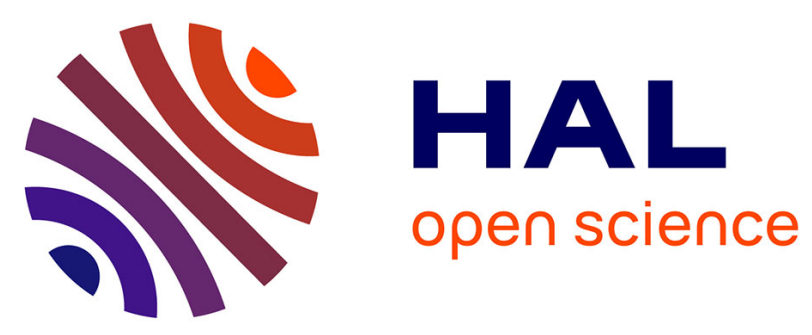

\title{
Di-(2-ethylhexyl)-phthalate (DEHP) activates the Constitutive Androstane Receptor (CAR): a novel signalling pathway sensitive to phthalates
}

Alexandre Eveillard, Laila Mselli-Lakhal, Ariane Mogha, Frédéric Lasserre, Arnaud Polizzi, Jean-Marc Pascussi, Hervé Guillou, Pascal G.P. Martin, Thierry Pineau

\section{To cite this version:}

Alexandre Eveillard, Laila Mselli-Lakhal, Ariane Mogha, Frédéric Lasserre, Arnaud Polizzi, et al.. Di(2-ethylhexyl)-phthalate (DEHP) activates the Constitutive Androstane Receptor (CAR): a novel signalling pathway sensitive to phthalates. Biochemical Pharmacology, 2009, 77 (11), pp.1735. 10.1016/j.bcp.2009.02.023 . hal-00493499

\section{HAL Id: hal-00493499 https://hal.science/hal-00493499}

Submitted on 19 Jun 2010

HAL is a multi-disciplinary open access archive for the deposit and dissemination of scientific research documents, whether they are published or not. The documents may come from teaching and research institutions in France or abroad, or from public or private research centers.
L'archive ouverte pluridisciplinaire HAL, est destinée au dépôt et à la diffusion de documents scientifiques de niveau recherche, publiés ou non, émanant des établissements d'enseignement et de recherche français ou étrangers, des laboratoires publics ou privés. 


\section{Accepted Manuscript}

Title: Di-(2-ethylhexyl)-phthalate (DEHP) activates the Constitutive Androstane Receptor (CAR): a novel signalling pathway sensitive to phthalates

Authors: Alexandre Eveillard, Laila Mselli-Lakhal, Ariane

Mogha, Frédéric Lasserre, Arnaud Polizzi, Jean-Marc

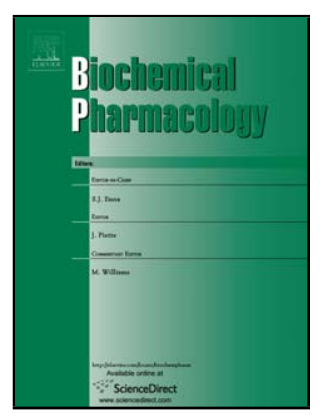

Pascussi, Hervé Guillou, Pascal G.P. Martin, Thierry Pineau

PII: $\quad$ S0006-2952(09)00149-X

DOI: $\quad$ doi:10.1016/j.bcp.2009.02.023

Reference: $\quad$ BCP 10104

To appear in: $\quad B C P$

Received date: $\quad 22-12-2008$

Revised date: 25-2-2009

Accepted date: $\quad$ 25-2-2009

Please cite this article as: Eveillard A, Mselli-Lakhal L, Mogha A, Lasserre F, Polizzi A, Pascussi J-M, Guillou H, Martin PGP, Pineau T, Di-(2-ethylhexyl)phthalate (DEHP) activates the Constitutive Androstane Receptor (CAR): a novel signalling pathway sensitive to phthalates, Biochemical Pharmacology (2008), doi:10.1016/j.bcp.2009.02.023

This is a PDF file of an unedited manuscript that has been accepted for publication. As a service to our customers we are providing this early version of the manuscript. The manuscript will undergo copyediting, typesetting, and review of the resulting proof before it is published in its final form. Please note that during the production process errors may be discovered which could affect the content, and all legal disclaimers that apply to the journal pertain. 


\title{
Di-(2-ethylhexyl)-phthalate (DEHP) activates the Constitutive Androstane
} Receptor (CAR): a novel signalling pathway sensitive to phthalates.

\author{
Alexandre Eveillard ${ }^{\mathrm{a}, \mathrm{t}}$, Laïla Mselli-Lakhal ${ }^{\mathrm{a}, \mathrm{t}}$, Ariane Mogha ${ }^{\mathrm{a}, \mathrm{b}}$, Frédéric Lasserre ${ }^{\mathrm{a}}$, \\ Arnaud Polizzi ${ }^{\text {a }}$, Jean-Marc Pascussi ${ }^{c}$, Hervé Guillou ${ }^{a}$, Pascal G.P. Martin ${ }^{\mathrm{a}}$, and Thierry \\ Pineau ${ }^{\mathrm{a}, \#}$.
}

${ }^{a}$ Laboratoire de Pharmacologie et Toxicologie Institut National de la Recherche Agronomique INRA UR66 Toulouse, France.

${ }^{\mathrm{b}}$ Current address: CNRS UMR6061, Faculté de médecine, 2 avenue du Professeur Léon Bernard, 35043 Rennes, France

c Inserm U.632, IFR 122, Université de Montpellier 1, Campus CNRS, 1919, route de Mende, 34293 Montpellier, France.

${ }^{\dagger}$ These authors equally contributed to this work.

${ }^{\#}$ Corresponding author

Running title: Di-(2-ethylhexyl)-phthalate activates CAR

Keywords: toxicology $\bullet$ phthalates $\bullet$ endocrine disruptors $\bullet$ androstane receptor $\bullet$ metabolic syndrome

Correspondence: Thierry Pineau, Pôle de Toxicologie Alimentaire, Laboratoire de Pharmacologie et Toxicologie, INRA UR66, 180 Chemin de Tournefeuille, Toulouse Cedex 9, F31931, France. E-mail: Thierry.Pineau@toulouse.inra.fr

Classification: (6) Toxicology

Disclosure statement: The authors have nothing to disclose 
Di-(2-ethylhexyl)-phthalate (DEHP), a widely used plasticizer, is detected in consumer's body fluids. Contamination occurs through environmental and food chain sources. In mouse liver, DEHP activates the peroxisome proliferator-activated receptor alpha (PPAR $\alpha)$ and regulates the expression of its target genes. Several in vitro investigations support the simultaneous recruitment of additional nuclear receptor pathways.

We investigated, in vivo, the hepatic impact of low doses of DEHP on PPAR $\alpha$ activation, and the putative activation of additional signalling pathways. Wild-type and PPAR $\alpha$-deficient mice were exposed to different doses of DEHP. Gene expression profiling delineated the role of PPAR $\alpha$ and revealed a PPAR $\alpha$-independent regulation of several prototypic Constitutive Androstane Receptor (CAR) target genes. Thus, we developed an original hepatic cell line expressing CAR to investigate its activation by DEHP. By means of a pharmacological inhibitor or CAR-targeting shRNAs, we established that CAR is required for the effect of DEHP on Cyp2b10, a recognized CAR target gene. Moreover, DEHP dose-dependently induced CYP2B6 in human primary hepatocyte cultures.

This finding demonstrates that CAR also represents a transcriptional regulator sensitive to phthalates. CAR-mediated effects of DEHP provide a new rationale for most endpoints of phthalates toxicity described previously, including endocrine disruption, hepatocarcinogenesis and the metabolic syndrome. 


\section{Introduction}

Phthalates represent a leading class of chemical congeners which are used in a broad range of industrial applications including plasticized polyvinyl chloride [PVC], cosmetics, residential construction, automotive industries and medical products $[1,2]$. Since phthalates are not chemically bound to the products, they can leak, migrate or evaporate mostly from PVCcontaining goods, resulting in significant environmental contamination [3] and human exposure [4-7]. Di-(2-ethylhexyl)-phthalate (DEHP) is a widely used congener for which dietary exposure (food processing, packaging) likely represents the main source of contamination for the general population [5]. The highest levels of exposure have been reported in specific populations such as patients and neonates exposed to PVC medical devices [8] or PVC factory workers [9].

An important concern about DEHP relates to its potential to act as a nongenotoxic hepatocarcinogen in rodent species [10]. Initial experiments implicated PPAR $\alpha$-dependent mechanisms and suggested a controversial low relevance to humans [11, 12]. However, while PPAR $\alpha$-null mice (SV129 background) develop liver neoplasms under DEHP exposure [13] the mechanisms implicated may be slightly different from those elicited in wild-type mice [14]. Thus, this supports the need for more investigations to elucidate the mechanism leading to carcinogenesis.

Through experimental and epidemiology studies, evidence has accumulated for the association of other detrimental health effects with phthalate exposure. In mammals, including humans, phthalate exposure is associated with endocrine disruption [15-17] and metabolic disorders $[18,19]$. In rodents, in utero exposure to phthalates results in developmental and reproductive defects similar to those termed testicular dysgenesis syndrome in humans [20-22]. Furthermore, an association between phthalate exposure and subtle defects in genital tract development of male infants has been reported [23]. The underlying mechanisms may involve antiandrogenic or proestrogenic properties of phthalates that could disturb the gonadal 
development in the embryo through the modification of androgens bioavailability [24]. Sustained exposure to phthalates through adulthood could also contribute to decreased testosterone levels [9] or semen quality [25].

Recently, two independent cross sectional studies of the National Health And Nutrition Examination Survey [NHANES, 1999-2002] have provided consistent conclusions which associate several urinary phthalates metabolites with key features of the metabolic syndrome (body mass index, abdominal adiposity and insulin resistance) $[18,19]$. Based on several studies, it has been suggested that the onset of the metabolic syndrome could be favoured by prolonged exposure to low concentrations of environmental pollutants, including phthalates, which are collectively referred to as environmental obesogens $[18,26,27]$. However, the mechanisms involved in these new aspects of phthalate metabolic impact remain poorly understood. At the molecular level, the activation of the three isoforms of the peroxisome proliferator-activated receptor (PPAR, $\alpha, \beta, \gamma)$ by phthalate metabolites and the resulting metabolic consequences have been extensively documented [28]. In adipose cells, mono-ethylhexyl- phthalate (MEHP), a potent metabolite of DEHP, activates PPAR $\gamma(\mathrm{Nr} 1 \mathrm{c} 3)$ and promotes adipogenesis [29]. In liver, another metabolically relevant organ, phthalates activate PPAR $\alpha(\mathrm{Nr} 1 \mathrm{c} 1)$ and behave as prototypical peroxisome proliferators (PP) [30], with rodents being more responsive than primates [31]. Gene expression profiling studies have further confirmed the striking over representation of PP-responding genes in the liver of rodents exposed to DEHP $[32,33]$. Aside from PPAR $\alpha$-dependent effects, phthalates were shown to activate the murine and human pregnane $\mathrm{X}$ nuclear receptor (PXR, Nr1i2), thus increasing the transcription of cytochrome P450 3A (Cyp3A) [34, 35].

The main objective of this study was to investigate the influence of DEHP on the network of hepatic nuclear receptors, while leaving aside the PPAR $\alpha$-dependent response, which has already been well established. Using gene expression profiles dedicated to NR pathways, we 
identified the Constitutive Androstane Receptor (CAR, Nrli3) as a putative phthalate target. Then we developed specific recombinant cellular tools to establish that phthalates activate the CAR signalling pathway. Finally, we showed that DEHP dose-dependently induce the expression of the CAR target gene CYP2B6 in primary human hepatocytes. This original finding is discussed in view of the crucial role played by the liver in controlling energy homeostasis and the recent findings which associate phthalate exposure to the onset of the metabolic syndrome in men $[18,19]$.

\section{Materials and Methods}

\subsection{Materials}

Di-(2-ethylhexyl)-phthalate (DEHP) (CAS No. 117-81-7, $\geq 97 \%$ purity), $5 \alpha$-androst-16-en-3 $\alpha$-ol (androstenol), 1,4-bis[2-(3.5-Dichloropyridyloxy)]benzene (ТCPOBOP), dimethylsulfoxide (DMSO), dexamethasone, geneticin and sodium butyrate were purchased from Sigma (Lyon, France). Cell culture medium (DMEM), Fetal Bovine Serum (FBS), glutamine, penicillin and streptomycin, trypsine, lipofectamine 2000 and sodium pyruvate were purchased from Invitrogen (Cergy Pontoise, France). Mono-(2-ethylhexyl) phtalate (MEHP) was kindly provided by Dr Jegou (Inserm-U625, Rennes, France).

\subsection{Animals and maintenance}

Male PPAR $\alpha$-null mice on a C57BL/6J genetic background [36, 37], and aged-matched wildtype counterparts (Charles River, Les Oncins, France; 4 weeks acclimatization) were housed in polycarbonate cages at $22^{ \pm} 2^{\circ} \mathrm{C}$ on a 12 hour light/dark cycle and allowed free access to water and food. In vivo studies were conducted under European Union Guidelines for the use and care of laboratory animals and were approved by an independent ethics committee.

\subsection{Experimental design, body fluids and organs sampling}


At the age of 18 - 22 weeks with an average initial body weight of $26.6 \mathrm{~g}( \pm 1.8$; SD), mice from both genotypes were randomly assigned into six groups ( $\mathrm{n}=10$ per group). DEHP, in solution into corn oil, was administered for 21 days by daily gavages (corn oil control group, 20 or 200 $\mathrm{mg} / \mathrm{kg} /$ day of DEHP). Blood samples were collected at the retro-orbital sinus with heparin-coated capillaries on three days $(-1,10$ and 21$)$. Plasma was prepared by centrifugation at $16000 \mathrm{~g}$, for 10 min and kept at $-80^{\circ} \mathrm{C}$. At day 21 , mice were euthanized by cervical dislocation and the liver was removed, weighed, dissected, snap-frozen in liquid nitrogen and stored at $-80^{\circ} \mathrm{C}$ until being used for transcriptomic analysis.

\subsection{Transcriptomic analyses}

Organ-specific transcriptomic profiles were obtained using a nuclear receptors-dedicated cDNA macroarray (INRArray 01.4) previously developed and validated [38, 39]; full list of 320 cDNA probes available at http://www.inra.fr/internet/Centres /toulouse/pharmacologie/pharmaco-

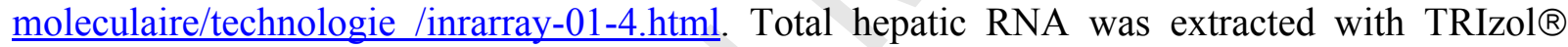
reagent (Invitrogen, Cergy Pontoise, France) according to the manufacturer's protocol. RNA integrity was controlled on a Bioanalyzer 2100 (Agilent, Massy, France) and assayed at $260 \mathrm{~nm}$ on a Lambda 650 spectrophotometer (Perkin Elmer, Toulouse, France). RNA labelling and hybridization to INRArray 01.4 were performed as previously described [39]. The raw and processed data are available in the Gene Expression Omnibus (GEO) database [40] under the accession number GSE14920.

For real-time quantitative PCR (Q-PCR), total RNA samples $(2 \mu \mathrm{g})$ were reverse-transcribed using SuperScript ${ }^{\mathrm{TM}}$ II reverse transcriptase (Invitrogen, Cergy Pontoise, France). Primers for SYBR Green assays are presented in Table 1. Amplifications were performed on an ABI Prism 7000 (Applied Biosystems, Courtaboeuf, France). Q-PCR data were normalized by TATA-box binding protein (TBP) mRNA levels and analyzed with DART-PCR [41].

\subsection{Statistical analysis of transcriptomic data}


Data were analyzed using R (www.r-project.org) with various packages from Bioconductor (www.bioconductor.org). Macroarray data pre-processing (filtering and normalization) and quality controls were described previously [42]. Differential effects were analyzed by ANOVA followed by a Student $t$ test with a pooled variance estimate. The Benjamini-Hochberg procedure was used to control the false discovery rate at $10 \%$. Principal component analysis (PCA), an unsupervised exploratory multidimensional analysis, was used to identify the main effects on the transcriptomic data set.

\subsection{DNA and shRNA constructs}

The pCR3-mCAR construct expressing the murine CAR [43] and the pEGFP-CAR [44] plasmid expressing a fusion protein between the green fluorescent protein (GFP) and the murine CAR were kindly provided by Dr. M Negishi. The pLKO-SH1012, pLKO-SH767, pLKO-SH1134, pLKO-SH648 and pLKO-SH504 HIV-1-derived lentiviral constructs (Sigma, Lyon, France) were used to knockdown the expression of CAR. The pLVTHM construct [45] is a HIV1-derived lentiviral vector carrying the GFP gene under the control of the Elongation Factor 1- $\alpha$ promoter. The packaging system is composed of the psPAX2 and pMD2.G plasmids (http://tronolab.epfl.ch/). All constructs were verified by sequence analysis.

\subsection{Cell culture and transfections}

JWZ murine hepatic cells, also referred to as MuSH immortalized hepatocytes [46], were kindly provided by Dr. JP Gray. 293FT cells were purchased from Invitrogen (Cergy Pontoise, France). Both cell lines were cultured in DMEM supplemented with L-glutamine (2mM), penicillin (100 $\mathrm{IU} / \mathrm{ml})$, streptomycin $(100 \mu \mathrm{g} / \mathrm{ml})$, and BFS $(10 \%)$. The culture medium of JWZ cells was supplemented with dexamethasone $(1 \mu \mathrm{M})$ and those of $293 \mathrm{FT}$ cells was supplemented with sodium pyruvate $(1 \mathrm{mM})$ and non-essential amino acids $(100 \mu \mathrm{M}$, Invitrogen, Cergy Pontoise, France). The pCR3-mCAR plasmid was transfected into the JWZ cells using lipofectamine 2000 according to the manufacturer's protocol. After 48 hours, the transfected cells were submitted to 
geneticin selection for 10-15 days. Individual resistant clones were harvested, amplified and cryopreserved before being tested for CAR transcript expression using Q-PCR.

The pLVTHM and the pEGFP-CAR plasmids were transfected into the JWZ cells using lipofectamine 2000. After 48 hours, the cells were transferred to LabTek chambered coversglasses (Nunc) for fluorescence analysis.

\subsection{Fluorescence analysis}

Cells adherent to the coverslips were fixed with $4 \%(w / v)$ paraformaldehyde (Sigma, Lyon France) in PBS. Coverslips were then mounted onto slides using prolong gold antifade reagent (Invitrogen, Cergy Pontoise, France) and visualized under a ZEISS LSM 510 laser scanning confocal microscope.

\subsection{Lentiviral ShRNA vectors production and JWZ-CAR cell transduction}

To produce the lentiviral particles, 293FT cells were cotransfected in suspension with the appropriate lentiviral-shRNA or control vector and the packaging constructs using lipofectamine 2000. After 24 hours the culture medium was replaced with fresh medium containing sodium butyrate $(10 \mathrm{mM})$ known to improve vector titers. Viral supernatants were harvested 48 hours after transfection, filtered $(0.45 \mu \mathrm{m})$ and titrated on $293 \mathrm{FT}$ cells by serial dilutions and fluorescence-activated cell sorter (FACS) analysis for the ratio of GFP positive cells. The vectors harbouring the puromycin-resistance gene in place of the GFP gene were titrated according to Sigma recommendations. Viral titers of $\sim 10^{5}$ transforming units $(\mathrm{TU}) / \mathrm{ml}$ were obtained. To isolate stable shRNA cell lines, JWZ-CAR (JWZ cells expressing active CAR) were infected with the viral vector stocks at a multiplicity of infection (MOI) of 1. Following puromycin selection (10-15 days) CAR and Cyp2b10 transcripts expression were measured by Q-PCR.

\subsection{Primary culture of human hepatocytes}

Human hepatocytes were prepared and cultured according to the previously published procedure [47]. CYP2B6 transcript expression was measured by Q-PCR. 


\section{Results}

\subsection{Hepatic impact of DEHP: gene profiling in wild-type and PPAR $\alpha$-deficient mice}

To evaluate the modulation by DEHP of hepatic NR pathways other than PPAR $\alpha$, we used a NR-dedicated cDNA macroarray (INRArray01.4) to profile hepatic gene expression in wild-type and PPAR $\alpha$-deficient mouse liver orally exposed to DEHP. We analyzed the hepatic gene expression profile of 60 mice ( 30 of each genotype, $n=10$ per group) which were treated for 3 weeks with 0,20 or $200 \mathrm{mg} / \mathrm{kg} /$ day of DEHP. Noticeably, a $20 \mathrm{mg} / \mathrm{kg} /$ day dose (corresponding to a diet contamination of $\sim 0.02 \%$ ) is within the low range of doses inducing liver tumors during long-term exposures in rodents [13, 48]. 284 genes with measurable expression levels were initially retained for further analysis. One third ( 88 genes), displayed a significant regulation in at least one of the experimental conditions (genotype or treatment effects, Table 2). These regulated genes were assigned to 8 major biological functions (Table 2). Fatty acid homeostasis and xenobiotic metabolism were the most represented pathways. 56 transcripts were differentially expressed between wild-type and PPAR $\alpha$-deficient control mice. Interestingly, while DEHP (high dose) influenced 49 transcripts in wild type mice, 16 modulations were recorded in PPAR $\alpha$-deficient livers, and the following 4 regulations occurred in both genotypes: acylCoenzyme A oxidase1 (Acox1), aldehyde deshydrogenase family 1 subfamily 1a1 (Aldh1a1), aminolevulinic acid synthase 1 (Alas1) and cytochrome P450 2c29 (Cyp2c29). The 88 transcripts (Table 2) and the 60 samples were subjected to Principal component analysis (PCA) to identify patterns of coregulations that failed to be identified through gene-by-gene statistical tests. The first plane displayed more than $60 \%$ of the total variance within the dataset (Fig.1). Wild-type and PPAR $\alpha$-deficient samples were clearly separated along the first principal component (PC1, Fig.1A, squares versus circles). Additionally, the livers from wild-type mice exposed to DEHP (200 mg/kg/day) were also separated from controls along this axis (Fig.1A, black squares). Thus, 
PC1 captured a constitutive genotype effect and a PPAR $\alpha$-dependent effect of DEHP, both effects affecting similar genes. These genes are the longer vectors displaying a low angle with PC1 on the loading plot in Fig.1B, such as Cyp4a10, Ech1, Scd1, Angpt14, Cyp4a14, Cdkn1, Acox, Peci, Apoa4 or Slcola1. Most of these genes are well-known PPAR $\alpha$ targets [49]. Remarkably, when considering PC2 alone, the impact of DEHP exposure (200 mg/kg/day) was noticed for both genotypes (overall position of black circles and squares within the upper half of PC2). The loading plot (Fig.1B) indicated that the following transcripts were co-ordinately increased by DEHP in both genotypes: Papss2, Cyp2b10, Gstt3, Abcc3, Nr1i3/CAR, Sult1d1, Cyp2c29 and Alas1. Strikingly, CAR itself and several downstream targets of CAR were found in this list. This raised the possibility that DEHP could recruit the CAR signalling pathway, in vivo, in the liver.

\subsection{Modulation of CAR target transcripts following DEHP exposure in vivo}

To further strengthen a hypothetical activation of CAR following DEHP exposure, we confirmed key findings of the initial gene profiling study by QPCR. Cytochrome P450 4a14 (Cyp4a14) [50] and vanin1 (Vnn1) [51] are two PPAR $\alpha$ target genes which were expected to respond to the treatment. Both genes exhibited an altered constitutive expression in PPAR $\alpha$ deficient mice (Fig.2) and were substantially up-regulated by DEHP in wild-type mice only (Cyp4a14: 4.8- and 29.7-fold at 20 and $200 \mathrm{mg} / \mathrm{kg} /$ day DEHP, respectively, Vnn1: 5.2-fold at $200 \mathrm{mg} / \mathrm{kg} /$ day DEHP), even at the lowest dose (Cyp4a14).

Then we analyzed four transcripts which have been previously reported to undergo, to various levels, the influence of CAR. Cyp2b10 transcript was markedly up-regulated by DEHP in wild-type mice (6.6 fold-change, $200 \mathrm{mg} / \mathrm{kg} / \mathrm{day}$ ), and was concomitantly modulated, but to a lower extent, in PPAR $\alpha$-null mice (2.8 fold-increase) (Fig.3A). For Cyp2c29, Cyp3a11 and Alas1, first, we noticed significantly lower constitutive expression levels in PPAR $\alpha$-null mice compared to wild-type mice (2.0, 2.7 and 2.6-fold decrease respectively) (Fig.3B-D). Cyp2c29 
transcript responded significantly to both doses of DEHP in wild-type mice and responded to the same extent to the higher dose of DEHP even in the PPAR $\alpha$-null mice (1.6 fold-changes in both genotypes) (Fig.3B). Cyp3a11 displayed a modest, but significant, increase in wild-type mice only (x 1.5, $200 \mathrm{mg} / \mathrm{kg} /$ day DEHP) (Fig.3C). Alas1 was up-regulated by DEHP, in both genotypes, in comparable proportions (Fig.3D).

When we submitted the 88 genes in Table 2 to Ingenuity Pathways Analysis (IPA), the CAR pathway was found to be significantly over-represented compared to the macroarray composition. Out of the 21 genes which undergo the influence of CAR, according to Ingenuity Knowledge base (Fig.3E), 13 were spotted on our macroarray (genes in grey in Fig.3E). 9 genes out of these 13 (asterisks in Fig.3E), participated to PC2. This further supported the existence of a PPAR $\alpha$-independent response to DEHP.

Based on these initial results which strongly suggested the activation of the CAR signalling pathway by phthalates, we initiated a set of experiments to establish this proposal.

\subsection{Establishment of hepatocyte cell lines expressing a functional CAR}

As a prerequisite we had to develop a stable cell line expressing the functional CAR. An initial screening conducted on readily available hepatic cell lines, revealed that the JWZ (MuSH) [46] and the Hepa-I lines expressed standard levels of Retinoid X Receptor (RXR), the heterodimeric partner of CAR, while CAR transcript was barely or not detectable (QPCR experiments, data not shown). Using the pCR3-mCAR expression vector, we established Hepa-ICAR and JWZ-CAR cell lines which stably expressed the murine CAR nuclear receptor. Based on further functional test results (not shown), we selected the JWZ-CAR line for this study. In this line, the expression of the CAR transcript was 60 -fold higher than in the parental JWZ cells (Fig.4A). Consequently, this resulted in a 10-fold constitutive increase in Cyp2b10 mRNA expression, a known downstream target of CAR (Fig.4A). This suggested a spontaneous, and at least partly, nuclear localization of the active CAR protein in our JWZ-CAR line; a pattern 
previously reported in HepG2 cells [44]. Indeed, we confirmed this assumption by expressing a CAR-green fluorescent protein (GFP) fusion protein. The transfection of native JWZ cells with a plasmid expressing GFP alone (pLVTHM) led to a conventional cytoplasmic localization of the fluorescence (Fig.4B, upper lane pictures), while the same experiment with the CAR-GFP fusion protein revealed a fluorescence which was restricted to the nucleus (Fig.4B, lower lane pictures). Thus, in our JWZ-CAR model, CAR is localized in the nucleus and its constitutive activity increases the expression of its prototypic target gene Cyp2b10.

For further functional investigations, we developed a panel of JWZ-CAR sub lines stably expressing shRNAs targeting CAR. Out of the five shRNA-carrying lentiviral vectors tested, two constructs displayed a convincing efficacy to lower CAR expression. We measured a reduction of $63 \%$ and $69 \%$ of CAR mRNA level with pLKO-SH1012 and pLKO-SH767, respectively (Fig.4C). This translated into the parallel reduction of the constitutive level of the Cyp2b10 mRNA by $69 \%$ and $70 \%$ (Fig.4C).

\subsection{DEHP regulates gene expression through the CAR signalling pathway}

Firstly, we evaluated the response of the CAR pathway to an agonist (TCPOBOP, [52]) or an inverse agonist (androstenol, [53]) in the JWZ-CAR recombinant cells. TCPOBOP doubled the level of Cyp2b10. Androstenol, which alone reduced Cyp2b10 constitutive expression, abolished Cyp2b10 induction by TCPOBOP (Fig.5A, columns 1-4).

The in vivo effect of DEHP on Cyp2b10 hepatic transcript was reproduced (Fig.5A) in the recombinant JWZ-CAR cell line. Indeed, the incubation of the cells with $100 \mu \mathrm{M}$ of DEHP resulted in a two-fold increase of Cyp2b10 mRNA, equivalent to that observed with TCPOBOP (Fig.5A, column 5). Similarly, androstenol abolished the induction of Cyp2b10 by DEHP, thus supporting the involvement of CAR in this regulation (Fig.5A, column 6). In our JWZ-CAR cell line MEHP $(100 \mu \mathrm{M})$, the main DEHP metabolite, was unable to increase Cyp2b10 mRNA (Fig.5B). 
Finally, using the SH1012 and SH767 cell lines expressing CAR-targeting shRNAs, we showed that a $\sim 60 \%$ reduction in CAR expression led to a loss of the ability to modulate Cyp2b10 mRNA level by TCPOBOP, androstenol, or DEHP (Fig.5C). Thus, this established that, like TCPOBOP, DEHP regulates the prototypic Cyp2b10 target by activating CAR.

\subsection{DEHP regulates CYP2B6 expression in human primary hepatocytes}

To evaluate whether the activation of CAR by DEHP could be extrapolated to humans, we tested the effects of DEHP on CYP2B6 expression in two independent cultures of human primary hepatocytes. Consistently, DEHP dose-dependently increased the expression of CYP2B6 at 50 and $100 \mu \mathrm{M}$ of DEHP in both primary hepatocyte cultures (Fig.6).

\section{Discussion}

Human exposure to phthalates inevitably occurs due to their use in plastics and consumer products [2]. In the adult, the main concerns associated to phthalate exposure are linked to hepatocarcinogenesis [10], endocrine [9, 25] and metabolic disruption [27]. Despite many studies, the mechanisms involved in these effects remain poorly understood.

In this study, we confirm the responsiveness of PPAR $\alpha$ pathway to DEHP (activation even at the $20 \mathrm{mg} / \mathrm{kg} /$ day low dose, Fig.2A). And when abrogating the dominant signal elicited by PPAR $\alpha$ using PPAR $\alpha$-null mice, we revealed the underlying activation of the hepatic CAR pathway (Table 2, Fig.1 and 3). The activation of CAR by DEHP was then demonstrated using a CAR-expressing cell line which was exposed either to a CAR inverse agonist (androstenol, Fig.5A) or to shRNAs targeting CAR (Fig.5C).

Consistent with our finding, it was recently reported that DEHP may activate Cyp2b10 promoter, but this was done only with a gene reporter system [54]. Our study is the first report on DEHP activation of Cyp2b10 gene both in vitro and in vivo. It also provides the first in vitro demonstration that CAR is involved in the regulation of Cyp2b10 by DEHP, which could 
otherwise be attributed to PXR. CAR activation by phthalates may not be restricted to mice species and to DEHP since an other phthalate, the Di-n-butyl phthalate $(500 \mathrm{mg} / \mathrm{kg} / \mathrm{day})$ was shown to increase the CAR-target Cyp2b1 transcript in late rat embryos (E:19) [55]. Interestingly, another group has very recently reported that the CAR2 splice variant of human CAR is activated by DEHP [56]. Similar to their observations using in vitro reporter assays [56], we show here that MEHP, the main DEHP metabolite does not induce Cyp2b10 in our JWZCAR cell line. It remains to be established whether DEHP or one if its metabolite other than MEHP directly binds to mouse and/or human CAR.

CAR (Nr1i3) was first described as a xenobiotic-sensing nuclear receptor that regulates the expression of hepatic enzymes and transporters involved in xenobiotic metabolism [57]. It is closely related to PXR (Nr1i2) and these receptors share both ligands [58] and target genes [59]. Indeed, DEHP and MEHP also activate mouse and human PXR $[34,60]$ which result in CYP3A induction. In vivo, we observed a higher induction by DEHP of Cyp2b10 expression (Fig. 3A) compared to Cyp3a11 (Fig.3C), suggesting that the CAR pathway is at least as responsive as the PXR pathway to DEHP.

Importantly, the xenobiotic metabolizing systems induced by CAR and PXR are also involved in the metabolism of endogenous molecules including steroid and thyroid hormones. Both receptors protect the body from the deleterious accumulation of bilirubin $[61,62]$ and bile acids [63] through hepatic induction of several enzyme genes. Additionally, many CAR and PXR target genes, including CYP3A and CYP2B, are involved in steroid hormone metabolism and their induction could contribute to the endocrine disruption activities of drugs and contaminants $[64,65]$. CYP2B6 induction following DEHP exposure of human hepatocytes confirmed a possible extrapolation to humans of this DEHP-mediated CAR activation observed in mice (Fig.6, [56]). This induction could contribute to increased hepatic testosterone metabolism, 
leading to a reduction of circulating testosterone levels as observed in workers exposed to high levels of phthalates [9].

Similarly, the CAR-dependent induction of genes involved in hepatic phase II xenobiotic metabolism is responsible for increased thyroid hormone metabolism [66]. Consistently, CARdeficient mice loose more weight than wild-type controls during caloric restriction, likely due to a higher metabolic rate driven by higher thyroid hormone levels [67]. Interestingly, recent studies have suggested an inverse association between phthalate exposure and thyroid hormone levels in men [68] and pregnant women [69]. Given our observations, it is conceivable that CAR activation by DEHP contributes to a reduction in thyroid hormones which could favor a positive energy balance and weight gain in a context of high caloric intake. Accordingly, we have observed that high DEHP exposure $(1100 \mathrm{mg} / \mathrm{Kg} /$ day for 2 weeks) led to a significant reduction in plasma total T4 (data not shown). CAR and PXR are also increasingly recognized as important regulators of genes involved in lipid and glucose homeostasis (for review: [70, 71]. In particular, CAR activation reduces the expression of critical genes involved in fatty acid oxidation [72], bile acid synthesis and gluconeogenesis [73]. Further studies should evaluate the potential role of these regulations in mediating metabolic disruption by phthalates in light of their potential to activate both PXR and CAR.

Finally, CAR also mediates the hepatocarcinogenic effects of its xenobiotic ligands [74], suggesting that it may contribute to PPAR $\alpha$-independent hepatocarcinogenesis [13] following high dose DEHP exposure. Indeed, we have observed that high DEHP exposure (1100 $\mathrm{mg} / \mathrm{kg} / \mathrm{day}, 14$ days) in mice induces the hepatic expression of Mdm2 (2.1-fold, data not shown), a direct CAR target gene that contributes to hepatocyte proliferation [74].

Overall, our results demonstrate that DEHP activates the CAR pathway which results in the induction of several hepatic target genes in vivo. This adds DEHP to the growing list of environmental contaminants activating CAR [54, 75-77], further stressing the need to evaluate 
the specific role of this NR in mediating the array of deleterious carcinogenic, endocrine and metabolic effects associated with exposure to these compounds and their mixtures.

\section{Acknowledgements}

We acknowledge the excellent technical assistance of Colette Bétoulières and Gérard Galy. We thank Dr Joshua Grey for providing the JWZ (MuSH) cell line. We are grateful to Dr Catherine Viguié for her help with thyroid hormone assays. This work was supported by a grant from ANR (PNRA-PlastImpact program). A.E. was recipient of a fellowship from MESR.

\section{References}

[1] ATSDR. Agency for Toxic Substances and Disease Registry, Toxicological Profile for Di(2-ethylhexyl)phthalate (DEHP). Atlanta, GA. 2002.

[2] Hauser R, Calafat AM. Phthalates and human health. Occup Environ Med 2005;62:80618.

[3] Clark K, Cousins IT, Mackay D, Yamada K. Observed concentrations in the environment. In: C. A. Staples, ed.^eds. The Handbook of Environmental Chemistry. ed. New York: Springer-Verlag. 2003:125-77.

[4] CDC. Centers for Disease Control and Prevention. Third National Report on Human Exposure to Environmental Chemicals. Atlanta, GA. 2005.

[5] Wormuth M, Scheringer M, Vollenweider M, Hungerbuhler K. What are the sources of exposure to eight frequently used phthalic acid esters in Europeans? Risk Anal 2006;26:803-24.

[6] Heudorf U, Mersch-Sundermann V, Angerer J. Phthalates: toxicology and exposure. Int J Hyg Environ Health 2007;210:623-34.

[7] Clewell RA, Kremer JJ, Williams CC, Campbell JL, Jr., Andersen ME, Borghoff SJ. Tissue exposures to free and glucuronidated monobutylyphthalate in the pregnant and fetal rat following exposure to di-n-butylphthalate: evaluation with a PBPK model. Toxicol Sci 2008;103:241-59.

[8] Tickner JA, Schettler T, Guidotti T, McCally M, Rossi M. Health risks posed by use of Di-2-ethylhexyl phthalate (DEHP) in PVC medical devices: a critical review. Am J Ind Med 2001;39:100-11.

[9] Pan G, Hanaoka T, Yoshimura M, Zhang S, Wang P, Tsukino H, et al. Decreased serum free testosterone in workers exposed to high levels of di-n-butyl phthalate (DBP) and di2-ethylhexyl phthalate (DEHP): a cross-sectional study in China. Environ Health Perspect 2006;114:1643-8.

[10] Ito Y, Nakajima T. PPARalpha- and DEHP-Induced Cancers. PPAR Res 2008;2008:759716.

[11] Melnick RL. Is peroxisome proliferation an obligatory precursor step in the carcinogenicity of di(2-ethylhexyl)phthalate (DEHP)? Environ Health Perspect 2001;109:437-42. 
[12] Willhite CC. Weight-of-evidence versus strength-of-evidence in toxicologic hazard identification: Di(2-ethylhexyl)phthalate (DEHP). Toxicology 2001;160:219-26.

[13] Ito Y, Yamanoshita O, Asaeda N, Tagawa Y, Lee CH, Aoyama T, et al. Di(2ethylhexyl)phthalate induces hepatic tumorigenesis through a peroxisome proliferatoractivated receptor alpha-independent pathway. J Occup Health 2007;49:172-82.

[14] Takashima K, Ito Y, Gonzalez FJ, Nakajima T. Different mechanisms of DEHP-induced hepatocellular adenoma tumorigenesis in wild-type and Ppar alpha-null mice. J Occup Health 2008;50:169-80.

[15] Parks LG, Ostby JS, Lambright CR, Abbott BD, Klinefelter GR, Barlow NJ, et al. The plasticizer diethylhexyl phthalate induces malformations by decreasing fetal testosterone synthesis during sexual differentiation in the male rat. Toxicol Sci 2000;58:339-49.

[16] Andrade AJ, Grande SW, Talsness CE, Grote K, Golombiewski A, Sterner-Kock A, et al. A dose-response study following in utero and lactational exposure to di-(2-ethylhexyl) phthalate (DEHP): effects on androgenic status, developmental landmarks and testicular histology in male offspring rats. Toxicology 2006;225:64-74.

[17] Hauser R, Meeker JD, Duty S, Silva MJ, Calafat AM. Altered semen quality in relation to urinary concentrations of phthalate monoester and oxidative metabolites. Epidemiology 2006;17:682-91.

[18] Stahlhut RW, van Wijngaarden E, Dye TD, Cook S, Swan SH. Concentrations of urinary phthalate metabolites are associated with increased waist circumference and insulin resistance in adult U.S. males. Environ Health Perspect 2007;115:876-82.

[19] Hatch EE, Nelson JW, Qureshi MM, Weinberg J, Moore LL, Singer M, et al. Association of urinary phthalate metabolite concentrations with body mass index and waist circumference: a cross-sectional study of NHANES data, 1999-2002. Environ Health 2008;7:27.

[20] Mahood IK, Scott HM, Brown R, Hallmark N, Walker M, Sharpe RM. In utero exposure to di(n-butyl) phthalate and testicular dysgenesis: comparison of fetal and adult end points and their dose sensitivity. Environ Health Perspect 2007;115 Suppl 1:55-61.

[21] Foster PM. Disruption of reproductive development in male rat offspring following in utero exposure to phthalate esters. Int J Androl 2006;29:140-7; discussion 81-5.

[22] Olesen IA, Sonne SB, Hoei-Hansen CE, Rajpert-DeMeyts E, Skakkebaek NE. Environment, testicular dysgenesis and carcinoma in situ testis. Best Pract Res Clin Endocrinol Metab 2007;21:462-78.

[23] Swan SH, Main KM, Liu F, Stewart SL, Kruse RL, Calafat AM, et al. Decrease in anogenital distance among male infants with prenatal phthalate exposure. Environ Health Perspect 2005;113:1056-61.

[24] Lee BM, Koo HJ. Hershberger assay for antiandrogenic effects of phthalates. J Toxicol Environ Health A 2007;70:1365-70.

[25] Hauser R. Urinary phthalate metabolites and semen quality: a review of a potential biomarker of susceptibility. Int J Androl 2008;31:112-7.

[26] Baillie-Hamilton PF. Chemical toxins: a hypothesis to explain the global obesity epidemic. J Altern Complement Med 2002;8:185-92.

[27] Grun F, Blumberg B. Perturbed nuclear receptor signaling by environmental obesogens as emerging factors in the obesity crisis. Rev Endocr Metab Disord 2007;8:161-71.

[28] Bility MT, Thompson JT, McKee RH, David RM, Butala JH, Vanden Heuvel JP, et al. Activation of mouse and human peroxisome proliferator-activated receptors (PPARs) by phthalate monoesters. Toxicol Sci 2004;82:170-82.

[29] Feige JN, Gelman L, Rossi D, Zoete V, Metivier R, Tudor C, et al. The endocrine disruptor monoethyl-hexyl-phthalate is a selective peroxisome proliferator-activated receptor gamma modulator that promotes adipogenesis. J Biol Chem 2007;282:19152-66. 
[30] Lapinskas PJ, Brown S, Leesnitzer LM, Blanchard S, Swanson C, Cattley RC, et al. Role of PPARalpha in mediating the effects of phthalates and metabolites in the liver. Toxicology 2005;207:149-63.

[31] Ito Y, Yamanoshita O, Kurata Y, Kamijima M, Aoyama T, Nakajima T. Induction of peroxisome proliferator-activated receptor alpha (PPARalpha)-related enzymes by di(2ethylhexyl) phthalate (DEHP) treatment in mice and rats, but not marmosets. Arch Toxicol 2007;81:219-26.

[32] Currie RA, Bombail V, Oliver JD, Moore DJ, Lim FL, Gwilliam V, et al. Gene ontology mapping as an unbiased method for identifying molecular pathways and processes affected by toxicant exposure: application to acute effects caused by the rodent nongenotoxic carcinogen diethylhexylphthalate. Toxicol Sci 2005;86:453-69.

[33] Wong JS, Gill SS. Gene expression changes induced in mouse liver by di(2-ethylhexyl) phthalate. Toxicol Appl Pharmacol 2002;185:180-96.

[34] Hurst $\mathrm{CH}$, Waxman DJ. Environmental phthalate monoesters activate pregnane $\mathrm{X}$ receptor-mediated transcription. Toxicol Appl Pharmacol 2004;199:266-74.

[35] Cooper BW, Cho TM, Thompson PM, Wallace AD. Phthalate induction of CYP3A4 is dependent on glucocorticoid regulation of PXR expression. Toxicol Sci 2008;103:268-77.

[36] Lee SS, Pineau T, Drago J, Lee EJ, Owens JW, Kroetz DL, et al. Targeted disruption of the alpha isoform of the peroxisome proliferator-activated receptor gene in mice results in abolishment of the pleiotropic effects of peroxisome proliferators. Mol Cell Biol 1995;15:3012-22.

[37] Costet P, Legendre C, More J, Edgar A, Galtier P, Pineau T. Peroxisome proliferatoractivated receptor alpha-isoform deficiency leads to progressive dyslipidemia with sexually dimorphic obesity and steatosis. J Biol Chem 1998;273:29577-85.

[38] Martin PG, Lasserre F, Calleja C, Van Es A, Roulet A, Concordet D, et al. Transcriptional modulations by RXR agonists are only partially subordinated to PPARalpha signaling and attest additional, organ-specific, molecular cross-talks. Gene Expr 2005;12:177-92.

[39] Martin PG, Guillou H, Lasserre F, Dejean S, Lan A, Pascussi JM, et al. Novel aspects of PPARalpha-mediated regulation of lipid and xenobiotic metabolism revealed through a nutrigenomic study. Hepatology 2007;45:767-77.

[40] Barrett T, Troup DB, Wilhite SE, Ledoux P, Rudnev D, Evangelista C, et al. NCBI GEO: mining tens of millions of expression profiles--database and tools update. Nucleic Acids Res 2007;35:D760-5.

[41] Peirson SN, Butler JN, Foster RG. Experimental validation of novel and conventional approaches to quantitative real-time PCR data analysis. Nucleic Acids Res 2003;31:e73.

[42] Dejean S, Martin PG, Baccini A, Besse P. Clustering time-series gene expression data using smoothing spline derivatives. EURASIP J Bioinform Syst Biol 2007:70561.

[43] Ueda A, Kakizaki S, Negishi M, Sueyoshi T. Residue threonine 350 confers steroid hormone responsiveness to the mouse nuclear orphan receptor CAR. Mol Pharmacol 2002;61:1284-8.

[44] Kawamoto T, Sueyoshi T, Zelko I, Moore R, Washburn K, Negishi M. Phenobarbitalresponsive nuclear translocation of the receptor CAR in induction of the CYP2B gene. Mol Cell Biol 1999;19:6318-22.

[45] Wiznerowicz M, Trono D. Conditional suppression of cellular genes: lentivirus vectormediated drug-inducible RNA interference. J Virol 2003;77:8957-61.

[46] Tien ES, Gray JP, Peters JM, Vanden Heuvel JP. Comprehensive gene expression analysis of peroxisome proliferator-treated immortalized hepatocytes: identification of peroxisome proliferator-activated receptor alpha-dependent growth regulatory genes. Cancer Res 2003;63:5767-80. 
[47] Pichard L, Fabre I, Fabre G, Domergue J, Saint Aubert B, Mourad G, et al. Cyclosporin A drug interactions. Screening for inducers and inhibitors of cytochrome P-450 (cyclosporin A oxidase) in primary cultures of human hepatocytes and in liver microsomes. Drug Metab Dispos 1990;18:595-606.

[48] David RM, Moore MR, Cifone MA, Finney DC, Guest D. Chronic peroxisome proliferation and hepatomegaly associated with the hepatocellular tumorigenesis of $\operatorname{di}(2-$ ethylhexyl)phthalate and the effects of recovery. Toxicol Sci 1999;50:195-205.

[49] Mandard S, Muller M, Kersten S. Peroxisome proliferator-activated receptor alpha target genes. Cell Mol Life Sci 2004;61:393-416.

[50] Patsouris D, Reddy JK, Muller M, Kersten S. Peroxisome proliferator-activated receptor alpha mediates the effects of high-fat diet on hepatic gene expression. Endocrinology 2006;147:1508-16.

[51] Moffit JS, Koza-Taylor PH, Holland RD, Thibodeau MS, Beger RD, Lawton MP, et al. Differential gene expression in mouse liver associated with the hepatoprotective effect of clofibrate. Toxicol Appl Pharmacol 2007;222:169-79.

[52] Tzameli I, Pissios P, Schuetz EG, Moore DD. The xenobiotic compound 1,4-bis[2-(3,5dichloropyridyloxy)]benzene is an agonist ligand for the nuclear receptor CAR. Mol Cell Biol 2000;20:2951-8.

[53] Forman BM, Tzameli I, Choi HS, Chen J, Simha D, Seol W, et al. Androstane metabolites bind to and deactivate the nuclear receptor CAR-beta. Nature 1998;395:612-5.

[54] Baldwin WS, Roling JA. A Concentration Addition Model for the Activation of the Constitutive Androstane Receptor by Xenobiotic Mixtures. Toxicol Sci 2009;107:93-105.

[55] Wyde ME, Kirwan SE, Zhang F, Laughter A, Hoffman HB, Bartolucci-Page E, et al. Din-butyl phthalate activates constitutive androstane receptor and pregnane $\mathrm{X}$ receptor and enhances the expression of steroid-metabolizing enzymes in the liver of rat fetuses. Toxicol Sci 2005;86:281-90.

[56] Dekeyser JG, Stagliano MC, Auerbach SS, Prabu KS, Jones AD, Omiecinski CJ. Di(2ethylhexyl) phthalate is a highly potent agonist for the human constitutive androstane receptor splice variant, CAR2. Mol Pharmacol 2009:mol.108.053702.

[57] Swales K, Negishi M. CAR, driving into the future. Mol Endocrinol 2004;18:1589-98.

[58] Moore LB, Parks DJ, Jones SA, Bledsoe RK, Consler TG, Stimmel JB, et al. Orphan nuclear receptors constitutive androstane receptor and pregnane $\mathrm{X}$ receptor share xenobiotic and steroid ligands. J Biol Chem 2000;275:15122-7.

[59] Maglich JM, Stoltz CM, Goodwin B, Hawkins-Brown D, Moore JT, Kliewer SA. Nuclear pregnane $\mathrm{x}$ receptor and constitutive androstane receptor regulate overlapping but distinct sets of genes involved in xenobiotic detoxification. Mol Pharmacol 2002;62:638-46.

[60] Mnif W, Pascussi JM, Pillon A, Escande A, Bartegi A, Nicolas JC, et al. Estrogens and antiestrogens activate hPXR. Toxicol Lett 2007;170:19-29.

[61] Huang W, Zhang J, Chua SS, Qatanani M, Han Y, Granata R, et al. Induction of bilirubin clearance by the constitutive androstane receptor (CAR). Proc Natl Acad Sci U S A 2003;100:4156-61.

[62] Xie W, Yeuh MF, Radominska-Pandya A, Saini SP, Negishi Y, Bottroff BS, et al. Control of steroid, heme, and carcinogen metabolism by nuclear pregnane $\mathrm{X}$ receptor and constitutive androstane receptor. Proc Natl Acad Sci U S A 2003;100:4150-5.

[63] Guo GL, Lambert G, Negishi M, Ward JM, Brewer HB, Jr., Kliewer SA, et al. Complementary roles of farnesoid $\mathrm{X}$ receptor, pregnane $\mathrm{X}$ receptor, and constitutive androstane receptor in protection against bile acid toxicity. J Biol Chem 2003;278:4506271.

[64] Kretschmer XC, Baldwin WS. CAR and PXR: xenosensors of endocrine disrupters? Chem Biol Interact 2005;155:111-28. 
[65] Tabb MM, Blumberg B. New modes of action for endocrine-disrupting chemicals. Mol Endocrinol 2006;20:475-82.

[66] Qatanani M, Zhang J, Moore DD. Role of the constitutive androstane receptor in xenobiotic-induced thyroid hormone metabolism. Endocrinology 2005;146:995-1002.

[67] Maglich JM, Watson J, McMillen PJ, Goodwin B, Willson TM, Moore JT. The nuclear receptor CAR is a regulator of thyroid hormone metabolism during caloric restriction. $\mathrm{J}$ Biol Chem 2004;279:19832-8.

[68] Meeker JD, Calafat AM, Hauser R. Di(2-ethylhexyl) phthalate metabolites may alter thyroid hormone levels in men. Environ Health Perspect 2007;115:1029-34.

[69] Huang PC, Kuo PL, Guo YL, Liao PC, Lee CC. Associations between urinary phthalate monoesters and thyroid hormones in pregnant women. Hum Reprod 2007;22:2715-22.

[70] Moreau A, Vilarem MJ, Maurel P, Pascussi JM. Xenoreceptors CAR and PXR activation and consequences on lipid metabolism, glucose homeostasis, and inflammatory response. Mol Pharm 2008;5:35-41.

[71] Konno Y, Negishi M, Kodama S. The roles of nuclear receptors CAR and PXR in hepatic energy metabolism. Drug Metab Pharmacokinet 2008;23:8-13.

[72] Maglich JM, Lobe DC, Moore JT. The nuclear receptor CAR (NR1I3) regulates serum triglyceride levels under conditions of metabolic stress. J Lipid Res 2009;50:439-45.

[73] Miao J, Fang S, Bae Y, Kemper JK. Functional inhibitory cross-talk between constitutive androstane receptor and hepatic nuclear factor-4 in hepatic lipid/glucose metabolism is mediated by competition for binding to the DR1 motif and to the common coactivators, GRIP-1 and PGC-1alpha. J Biol Chem 2006;281:14537-46.

[74] Huang W, Zhang J, Washington M, Liu J, Parant JM, Lozano G, et al. Xenobiotic stress induces hepatomegaly and liver tumors via the nuclear receptor constitutive androstane receptor. Mol Endocrinol 2005;19:1646-53.

[75] Rosen MB, Lee JS, Ren H, Vallanat B, Liu J, Waalkes MP, et al. Toxicogenomic dissection of the perfluorooctanoic acid transcript profile in mouse liver: evidence for the involvement of nuclear receptors PPAR alpha and CAR. Toxicol Sci 2008;103:46-56.

[76] Huang W, Zhang J, Wei P, Schrader WT, Moore DD. Meclizine is an agonist ligand for mouse constitutive androstane receptor (CAR) and an inverse agonist for human CAR. Mol Endocrinol 2004; 18:2402-8.

[77] Hernandez JP, Huang W, Chapman LM, Chua S, Moore DD, Baldwin WS. The environmental estrogen, nonylphenol, activates the constitutive androstane receptor. Toxicol Sci 2007;98:416-26. 
Figure 1. Principal Component Analysis (PCA) of liver transcriptional signature. PCA was performed on a data set containing all 60 samples. 88 transcripts were initially analyzed for each sample. (A) Individual projection in PC1 and PC2 (first principal plan) is shown for liver of wildtype (square) and PPAR $\alpha^{-/-}$mice (circle) according to treatments of 20 (light grey), and 200 (black) $\mathrm{mg}$ of DEHP $/ \mathrm{kg} /$ day or vehicle (white). $\mathrm{n}=10$ animals in each treated or control group. (B) Correlation circle of gene expression variables. Genes with the highest correlation to the first plan are represented by vectors (corresponding names along dotted lines).

Figure 2. Effect of DEHP administration on hepatic mRNA levels of PPAR $\alpha$ dependent genes. Relative expressions of Cyp4a14 (A) and Vanin1 (B) mRNA were determined using Q-PCR normalized to the expression of TBP. Values shown are the mean \pm S.E.M. $(n=10$ for each group). Significant differences were analyzed by one-way ANOVA followed by Student's $t$ test. An asterisk (*) denotes a significant difference compared with control condition (vehicle alone) while a significant difference between the two genotypes was represented with "\#”. $P<0.05$.

Figure 3. Effect of DEHP administration on hepatic mRNA levels of CAR target genes. Relative expressions of Cyp2b10 (A), Cyp2c29 (B), Cyp3a11 (C) and Alas1 (D) mRNA were determined using Q-PCR normalized to the expression of TBP. Values shown are the mean \pm S.E.M. $(n=10$ for each group). Significant differences were analyzed by one-way ANOVA followed by Student's $t$ test. An asterisk (*) denotes a significant difference compared with control condition (vehicle alone) while a significant difference between the two genotypes was represented with “\#”. $P<0.05$. (E) Network representation of the genes identified by Ingenuity Pathway Analysis (IPA) in constitutive androstane receptor pathway. Grey indicates regulated genes in our study with treatment and/or genotype effect. Genes associated to the second axis of PCA (Fig. 1) were shown with an asterisk $(*)$.

Figure 4. New murine hepatocyte cell line expressing the CAR nuclear receptor and CAR directed shRNA. (A) Q-PCR results of relative expressions of CAR and Cyp2b10 in the parental JWZ cell line and the newly established JWZCAR cell line. Values shown are the mean \pm S.E.M. $(n=3$ for each cell line). (B) Analysis by confocal microscopy of subcellular localization of CAR protein in JWZ hepatocyte cell line. JWZ cells were transfected either with the pLVTHM vector expressing a native EGFP protein or the pEGFP-CAR construct expressing a EGFP-tagged CAR protein. (C) CAR and Cyp2b10 mRNA knockdown following infection of JWZCAR cell line with the lentiviral vectors pLKO-SH1012 or pLKO-SH767.

Figure 5. CAR dependent effect of DEHP and MEHP on Cyp2b10 mRNA levels. Cells were incubated for 48 hours in the presence of DMSO, TCPOBOP $(200 \mathrm{nM})$, androstenol $(5 \mu \mathrm{M})$, DEHP $(100 \mu \mathrm{M})$, MEHP $(100 \mu \mathrm{M})$ or a mix of TCPOBOP and androstenol or DEHP and androstenol. Cyp2b10 mRNA were then quantified by QPCR. Values shown are the mean \pm S.E.M. ( $n=3$ for each cell treatment).

(A) Cyp2b10 mRNA modulation after TCPOBOP, androstenol or DEHP treatment in the JWZCAR cell line. Significant differences were analyzed by one-way ANOVA followed by Student's $t$ test. An asterisk (*) denotes a significant difference compared with control condition (vehicle alone), $P<0.05$. (B) MEHP $(100 \mu \mathrm{M})$ does not induce Cyp2b10 expression in the JWZCAR cell line. (C) No more significant Cyp2b10 mRNA modulation after treatment with TCPOBOP, androstenol or DEHP in the CAR-knockdown cell lines (SH1012 and SH767). 
Figure 6. Effect of DEHP on CYP2B6 mRNA level in human primary hepatocytes. Q-PCR results of relative expressions of CYP2B6 in primary hepatocytes derived from 2 patients (patient1 and patient 2$)$ treated with 2 concentrations of DEHP $(50 \mu \mathrm{M}$ and $100 \mu \mathrm{M})$. 
Table 1: Oligonucleotides sequence for real time PCR

\begin{tabular}{llll}
\hline Gene & NCBI Refseq & Forward primer $\left(5^{\prime}-3^{\prime}\right)$ & Reverse primer $\left(5^{\prime}-3^{\prime}\right)$ \\
\hline Alas1 & NM_020559 & CAAAGAAACCCCTCCAGCC & GCTGTGTGCCGTCTGGAGT \\
CAR & NM_009803 & GCTGCAAGGGCTTCTTCAGA & CCTTCCAGCAAACGGACAGA \\
Cyp2b10 & NM_009999 & TTTCTGCCCTTCTCAACAGGAA & ATGGACGTGAAGAAAAGGAACAAC \\
Cyp2c29 & NM_007815 & GCTCAAAGCCTACTGTCA & CATGAGTGTAAATCGTCTCA \\
Cyp3a11 & NM_007818 & TCACACACACAGTTGTAGGCAGAA & GTTTACGAGTCCCATATCGGTAGAG \\
Cyp4a14 & NM_007822 & TCAGTCTATTTCTGGTGCTGTTC & GAGCTCCTTGTCCTTCAGATGGT \\
Tbp & NM_013684 & ACTTCGTGCAAGAAATGCTGAA & GCAGTTGTCCGTGGCTCTCT \\
Vnn1 & NM_011704 & ATGAGGTTTATGCCTTTGGAGC & CCACAGGTGCGTAAATTGGTAG \\
CYP2B6 & NM_000767 & GGCCATACGGGAGGCCCTTG & AGGGCCCCCTTGGATTTCCG \\
GAPDH & NM_002046 & GGTCGGAGTCAACGGATTTGGTCG & CAAAGTTGTCATGGATGACC \\
\hline
\end{tabular}


Table 2: Liver gene expression modulations induced by DEHP treatment Gene description

\begin{tabular}{|c|c|c|c|c|c|}
\hline & & & \\
\hline Function \& gene name & $\begin{array}{c}\text { GenBankTM } \\
\text { RefSeq }\end{array}$ & Symbol & $\begin{array}{l}\text { PPAR } \alpha-/- \\
200 / \text { ctrl }\end{array}$ & $\begin{array}{l}\text { Wild-type } \\
200 / \text { ctrl }\end{array}$ & $\begin{array}{l}\text { Untreated } \\
\text { PPAR } \alpha-1 \text { - wt }\end{array}$ \\
\hline fatty acid metabolism- . & 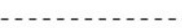 & & & & \\
\hline acetyl-Coenzyme A acyltransferase $1 \mathrm{~A}$ & NM_130864 & Acaa1a & & 2,9 & \\
\hline acetyl-Coenzyme A dehydrogenase, medium chain & NM_-007382 & Acadm & & 1,4 & \\
\hline acyl-CoA thioesterase 1 & NM_012006 & Acot1 & & 3,8 & \\
\hline acyl-Coenzyme A oxidase 1 , palmitoyl & NM_ 015729 & Acox1 & 1,3 & 2,7 & $-1,5$ \\
\hline cytochrome $\mathrm{P} 450$, family 2 , subfamily a, polypeptide 5 & NM_007812 & & 1,6 & & 1,8 \\
\hline cytochrome P450, family 4, subfamily a, polypeptide 10 & NM_010011 & Сур4а10 & & 5,4 & $\begin{array}{r}1,8 \\
-3,4\end{array}$ \\
\hline cytochrome P450, family 4, subfamily a, polypeptide 12 & NM_177406 & Сур4а12 & & 3,0 & $\begin{array}{r}-3,4 \\
1,5\end{array}$ \\
\hline cytochrome P450, family 4, subfamily a, polypeptide 14 & NM-007822 & Сур4а14 & & 7,6 & $-1,7$ \\
\hline dodecenoyl-Coenzyme $A$ delta isomerase $(3,2$ trans-enoyl-Coenyme $A$ isomerase $)$ & NM_010023 & Dci & & 1,7 & $\begin{array}{l}-1,1 \\
-1,3\end{array}$ \\
\hline enoyl coenzyme A hydratase 1 , peroxisomal & NM_016772 & Ech1 & & 1,8 & $\begin{aligned}-1,3 & \end{aligned}$ \\
\hline enoyl-Coenzyme A, hydratase/3-hydroxyacyl Coenzyme A dehydrogenase & $\mathrm{NM}_{-}^{-} 023737$ & Ehhadh & & 9,3 & \\
\hline hydroxyacyl-C oenzyme A dehydrogenase(trifunctional protein), alpha subunit & $\mathrm{NM}_{-}^{-} 178878$ & Hadha & & 1,4 & \\
\hline 3-hydroxy-3-methylglutaryl-Coenzyme A synthase 2 & $\mathrm{NM}_{-}^{-} 008256$ & Hmgcs2 & & 1,3 & $-1,9$ \\
\hline peroxisomal delta3, delta2-enoyl-Coenzyme $A$ isomerase & NM_-011868 & Peci & & 1,8 & $-1,8$ \\
\hline peroxisomal biogenesis factor $11 \mathrm{a}$ & NM_011068 & Pex11a & & 1,5 & \\
\hline solute carrier family 27 (fatty acid transporter), member 5 & NM_009512 & SIc27a5 & 1,3 & & \\
\hline $\begin{array}{l}\text { fatty acid transport- } \\
\text { ATP-binding cassette, sub-family D (ALD), member } 3\end{array}$ & NM 008991 & $A b c d 3$ & & 13 & \\
\hline 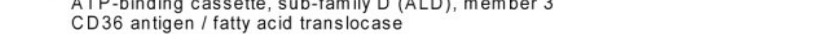 & NM_007643 & $\mathrm{Cd} 36$ & & 1,5 & \\
\hline carnitine palmitoyltransferase 2 & NM_-009949 & Cpt2 & & 1,4 & $-1,6$ \\
\hline diazepam binding inhibitor & NM_007830 & $\mathrm{Dbi}$ & & 1,6 & $-1,0$ \\
\hline fatty acid binding protein 1 , liver & NM_017399 & Fabp1 & & 2,0 & \\
\hline fatty acid binding protein 2 , intestinal & $\mathrm{NM}_{-}^{-007980}$ & Fabp2 & & 1,7 & \\
\hline 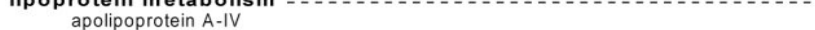 & NM 007468 & Apoa4 & & $-1,8$ & 8.4 \\
\hline apolipoprotein A-V & NM_080434 & Apoa5 & & & $-1,4$ \\
\hline apolipoprotein C-III & NM_-023114 & Apoc3 & & & 1,4 \\
\hline phospholipid transfer protein & NM_011125 & Pltp & & 1,4 & 1,7 \\
\hline scavenger receptor class $\mathrm{B}$, mem ber 1 & NM_016741 & Scarb1 & & & 1,4 \\
\hline very low density lipoprotein receptor & $\mathrm{NM}_{-}^{-} 013703$ & VIdlr & & 1,4 & $-1,6$ \\
\hline fatty acid sy nthesis is & NM 00703 & Elov13 & & & \\
\hline $\begin{array}{l}\text { elongation of very long chain fatty acids (FEN1/Elo2, SUR4/Elo3, yeast)-like } 3 \\
\text { fatty acid desaturase } 1\end{array}$ & NM- 007703 & $\begin{array}{l}\text { Elovi3 } \\
\text { Fads1 } 1\end{array}$ & & & $-2,0$ \\
\hline $\begin{array}{l}\text { fatty acid desaturase } 1 \\
\text { fatty acid desaturase } 2\end{array}$ & $\begin{array}{l}\text { NM_-146094 } \\
\text { NM_019699 }\end{array}$ & $\begin{array}{l}\text { Fads1 } \\
\text { Fads2 }\end{array}$ & & & $\begin{array}{l}-1,4 \\
-1,6\end{array}$ \\
\hline lipin 1 & NM_-015763 & Lpin 1 & & $-1,6$ & \\
\hline stearoyl-Coenzyme A desaturase, delta 9 desaturase & NM_-009127 & Scd1 1 & & 1,6 & $-4,3$ \\
\hline thyroid hormone responsive SPOT 14 homolog (Rattus) & $\mathrm{NM}_{-}^{-0} 09381$ & Thrsp & 1,7 & & 1,5 \\
\hline $\begin{array}{l}\text { cholesterol synthes is - } \\
\text { cytochrome P } 450 \text { family } 7 \text { subfamily b polypeptide } 1\end{array}$ & NM 007825 & Сур $7 \mathrm{~b} 1$ & & & 21 \\
\hline farnesyl diphosphate farnesyl transferase 1 . & NM_010191 & Fdft1 & & 1,5 & $\frac{2,1}{1,5}$ \\
\hline farnesyl diphosphate synthetase & $\mathrm{NM}_{-}^{-} 134469$ & Fdps & & 1,7 & 1,6 \\
\hline 3-hydroxy-3-methylglutaryl-Coenzyme A synthase 1 & NM_-145942 & $\mathrm{Hmgcs} 1$ & & 1,4 & 1,4 \\
\hline hydroxysteroid 11-beta dehydrogenase 1 & $\mathrm{NM}_{-}^{-} 008288$ & Hsd11b1 & 1,3 & & 1,4 \\
\hline hydroxysteroid (17-beta) dehydrogenase 4 & NM_008292 & Hsd17b4 & & 1,7 & \\
\hline $\begin{array}{l}\text { nobiotic metabolism- } \\
\text { ATP-binding cassette, sub-family C (CFTR/MRP), member } 2\end{array}$ & NM_013806 & $A b c c 2$ & & 1,4 & \\
\hline ATP-binding cassette, sub-family C (CFTR/MRP), member 3 & NM_-029600 & Abcc3 & & 1,3 & \\
\hline aldehyde dehydrogenase family 1 , subfamily $A 1$ & $\mathrm{NM}_{-}^{-} 013467$ & Aldh $1 \mathrm{a} 1$ & 1,6 & 1,4 & \\
\hline aldehyde dehydrogenase family 3 , subfamily A2 & NM_-007437 & Aldh $3 a 2$ & & 1,4 & \\
\hline cytochrome P 450 , family 1 , subfamily a, polypeptide 1 & NM_009992 & Сур1а1 1 & 1,5 & & 1,7 \\
\hline cytochrome P 450 , family 2 , subfamily b, polypeptide 10 & NM_009998 & Сур2b10 & 1,4 & & \\
\hline cytochrome P 450 , family 2 , subfamily c, polypeptide 29 & $\mathrm{NM}_{-}^{-} 007815$ & Сур2с29 & 1,7 & 1,4 & 1,5 \\
\hline cytochrome P 450 , family 2 , subfamily c, polypeptide 38 & NM_010002 & Сур2с38 & & & 1,4 \\
\hline cytochrome P 450 , family 2 , subfamily j, polypeptide 5 & NM_010007 & Сур $2 \mathrm{j} 5$ & & 1,3 & \\
\hline cytochrome P 450 , family 3 , subfamily a, polypeptide 11 & NM- 007818 & Сур3а11 & 2,0 & & $-2,0$ \\
\hline glutathione S-transferase, mu 1 & $\mathrm{NM}-010358$ & Gstm 1 & & 1,3 & \\
\hline glutathione S-transferase, theta 3 & NM_133994 & Gstt3 & 1,4 & & \\
\hline solute carrier family 10 (sodium/bile acid cotransporter family), member 1 & NM_011387 & SIc10a1 & & & 1,4 \\
\hline solute carrier organic anion transporter family, member $1 \mathrm{a} 1$ & NM_013797 & SIco1a1 & & & 1,4 \\
\hline solute carrier organic anion transporter family, member $1 \mathrm{a} 4$ & NM_-030687 & SIco1a4 & & & 2,0 \\
\hline sulfotransferase family 10 , member 1 & NM_016771 & 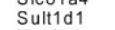 & & & 1,4 \\
\hline UDP glucuronosyltransferase 1 family, polypeptide A1 & NM_201645 & Ugt1a1 & 1,4 & & \\
\hline UDP glucuronosyltransferase 1 family, polypeptide $A 9$ & NM_201644 & Ugt1a9 & 1,3 & & \\
\hline ers. & NM 020559 & Alas 1 & 27 & & \\
\hline $\begin{array}{l}\text { aminolevulinic acid synthase } 1 \\
\text { actin, beta, cytoplasmic }\end{array}$ & $\begin{array}{l}\text { NM_020559 } \\
\text { NM_007393 }\end{array}$ & $\begin{array}{l}\text { Aast } 1 \\
\text { Actb } 1\end{array}$ & & 1,4 & \\
\hline $\begin{array}{l}\text { angiopoietin-like } 4 \\
\text { andin }\end{array}$ & NM_020581 & Angpt14 & & 1,4 & $-2,0$ \\
\hline B-cell leukemia/lym phoma 3 & NM_033601 & $\mathrm{Bcl} 3$ & & 1,4 & \\
\hline cyclin-dependent kinase inhibitor $1 \mathrm{~A}(P 21)$ & NM_007669 & Cdkn1a & & 1,4 & $-1,6$ \\
\hline glutam ate oxaloacetate transaminase 1 , soluble & $\mathrm{NM}-010324$ & Got1 & 1,5 & & \\
\hline gulonolactone (L-) oxidase & $\mathrm{NM}_{-}^{-} 178747$ & Gulo & & & 1,4 \\
\hline inhibitor of DNA binding 2 & NM-010496 & Id 2 & 1,4 & & \\
\hline inhibitor of kappaB kinase gamma & NM_ 010547 & Ikbkg & & & 2,2 \\
\hline lymphoid enhancer binding factor 1 & NM_010703 & Lef1 19 & & 1,8 & \\
\hline lipin 2 & NM_022882 & Lpin2 & & 1,4 & $-1,4$ \\
\hline 5,10 -methylenetetrahydrofolate reductase & NM_010840 & Mthfr & & & 2,2 \\
\hline 5-m ethyltetrahydrofolate-hom ocysteine meth yltransferase & XM_910457 & $\mathrm{Mtr}$ & & & 1,4 \\
\hline major urinary protein 2 & NM_008647 & Mup2 & & & 2,5 \\
\hline 3'-phosphoadenosine 5 '-phosphosulfate synthase 2 & $\mathrm{NM}-011864$ & Papss2 & & & 1,3 \\
\hline proliferating cell nuclear antigen & $\mathrm{NM}-011045$ & Pcna & & 1,3 & \\
\hline pyruvate dehydrogenase kinase, isoenzyme 4 & NM_013743 & $\mathrm{Pdk} 4$ & & 3,4 & \\
\hline paraoxonase 1 & NM_011134 & Pon1 & & & 1,3 \\
\hline peroxisome proliferative activated receptor, gamma, coactivator 1 beta & NM_133249 & Ppargc1b & & 1,5 & 1,5 \\
\hline $\begin{array}{l}\text { transformation related protein } 53 \\
\text {. }\end{array}$ & NM_011640 & Trp53 & & & 1,3 \\
\hline uncoupling protein 3 (mitochondrial, proton carrier) & $\mathrm{NM}_{-}^{-} 009464$ & Ucp3 & & & $-1,6$ \\
\hline uclear receptor- & & $\mathrm{Nr} 1 \mathrm{~h} 2$ & & 13 & \\
\hline $\begin{array}{l}\text { nuclear receptor subfamily } 1, \text { group } \mathrm{H}, \text { member } 2 \\
\text { nuclear receptor subfamily } 1, \text { group } \mathrm{I} \text {, member } 3\end{array}$ & NM_-009803 & $\mathrm{Nr}_{\mathrm{Ni}} \mathrm{ii} 2$ & & 1,3 & 1.4 \\
\hline nuclear receptor subfamily 4 , group A, member 1 & NM_-010444 & $\mathrm{Nr} 4 \mathrm{a} 1$ & & & 1,3 \\
\hline peroxisome proliferator activated receptor alpha & NM_-011144 & Ppara & & 1,3 & \\
\hline retinoic acid receptor, beta & $\mathrm{NM}_{-}^{-} 011243$ & Rarb & & & 1,4 \\
\hline retinoic acid receptor, gamma & NM_-011244 & Rarg & & & 1,6 \\
\hline thyroid hormone receptor alpha & NM_178060 & Thra & & 1,4 & $-1,4$ \\
\hline thyroid hormone receptor beta & NM_-009380 & Thrb & & & $-1,3$ \\
\hline vitam in $D$ receptor & NM_009504 & $\mathrm{Vdr}$ & & & $-1,5$ \\
\hline
\end{tabular}

The table reports the fold change of each DEHP-regulated transcript which has been recorded, in the liver, from macroarray analysis using INRArray 01.4 gene set. Significant differences were analyzed by one-way ANOVA followed by Student's $t$ test. Resulting $p$-values were adjusted by the Benjamini-Hochberg procedure to control the FDR at $10 \%$. Genes with adjusted $\mathrm{P}<0.10$ and with at least a 1.3-fold change in expression (induction or repression) are presented. 
Figure 1.

A.

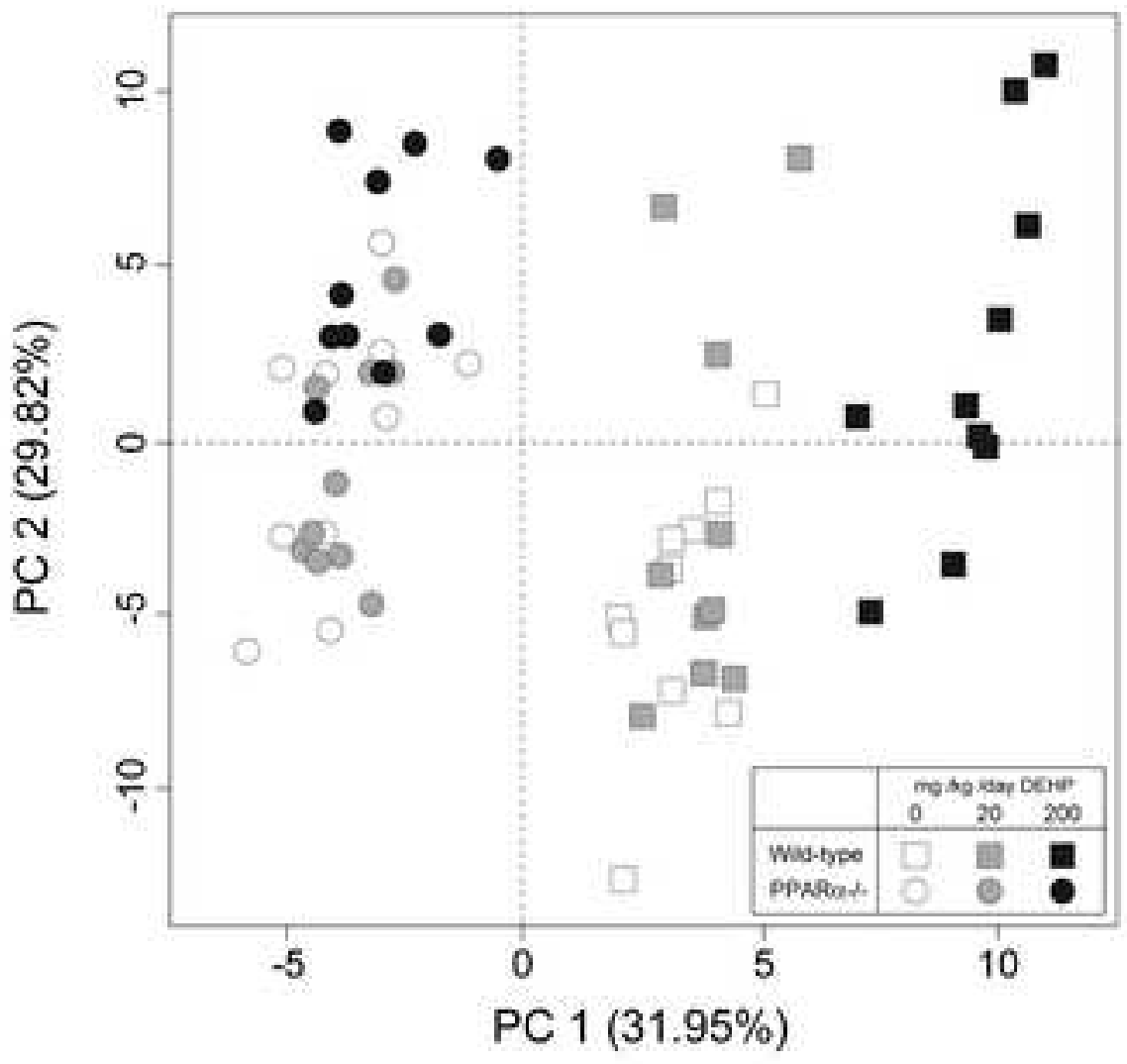

B.

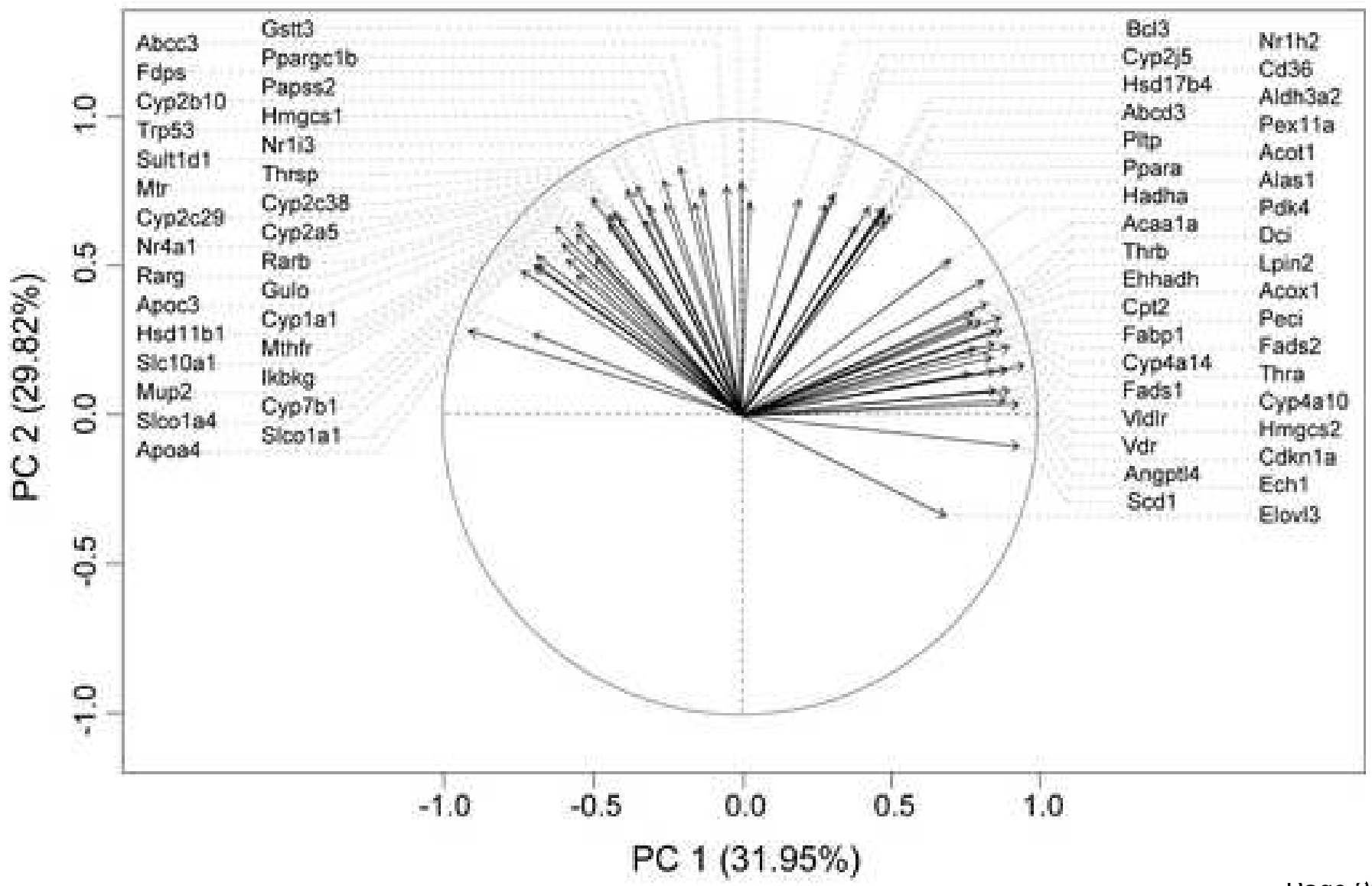


Figure 2.

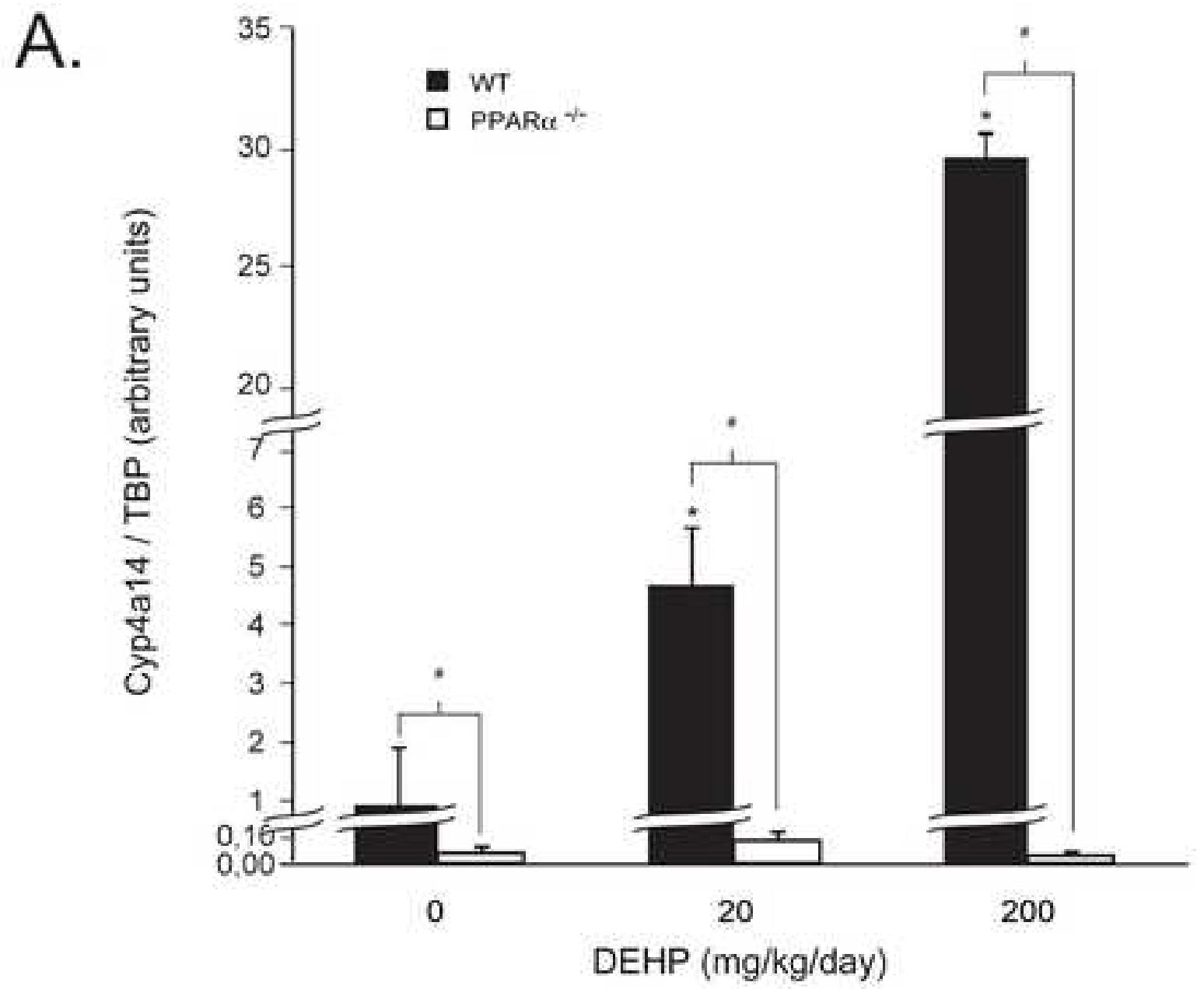

B.

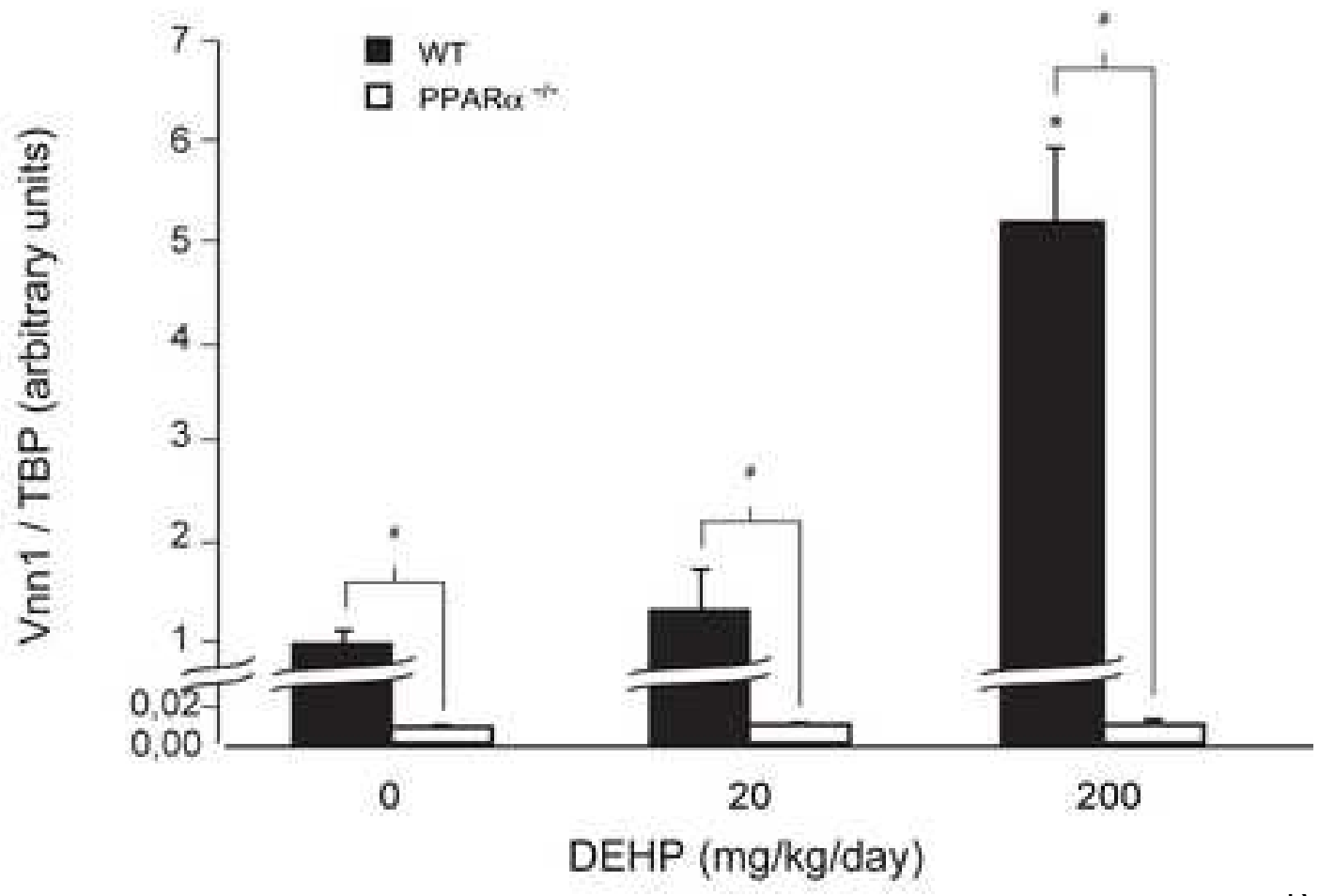


Figure 3.

A.

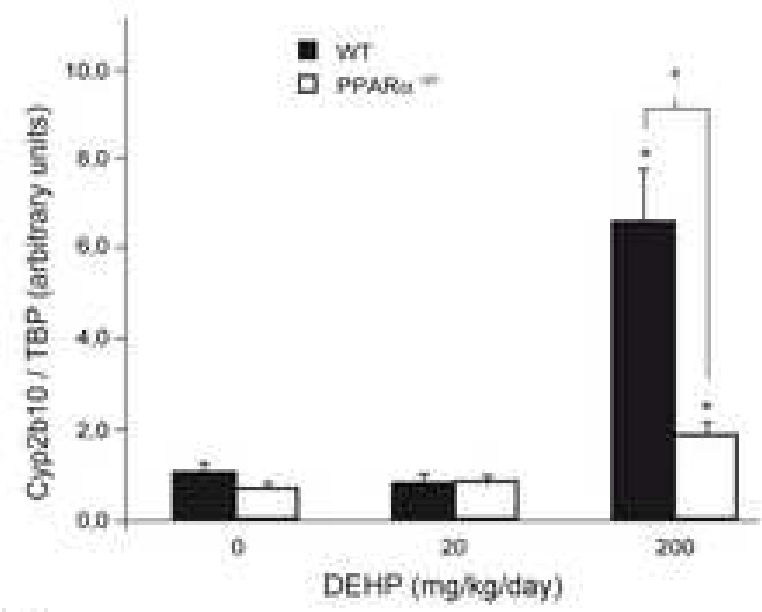

C.

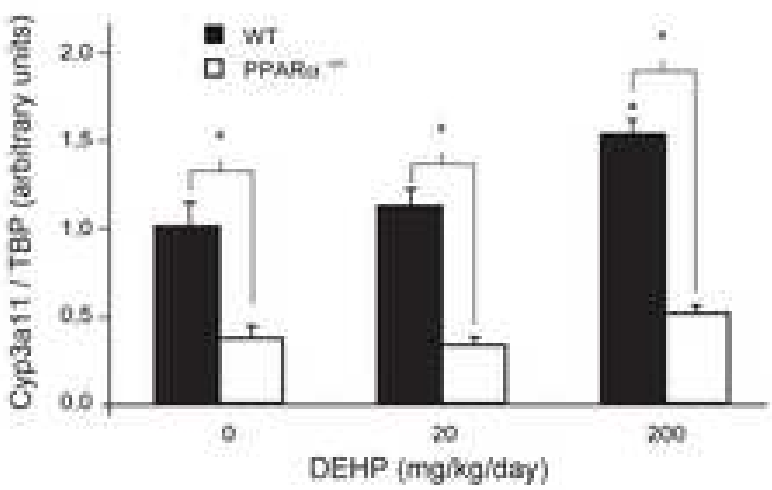

B.

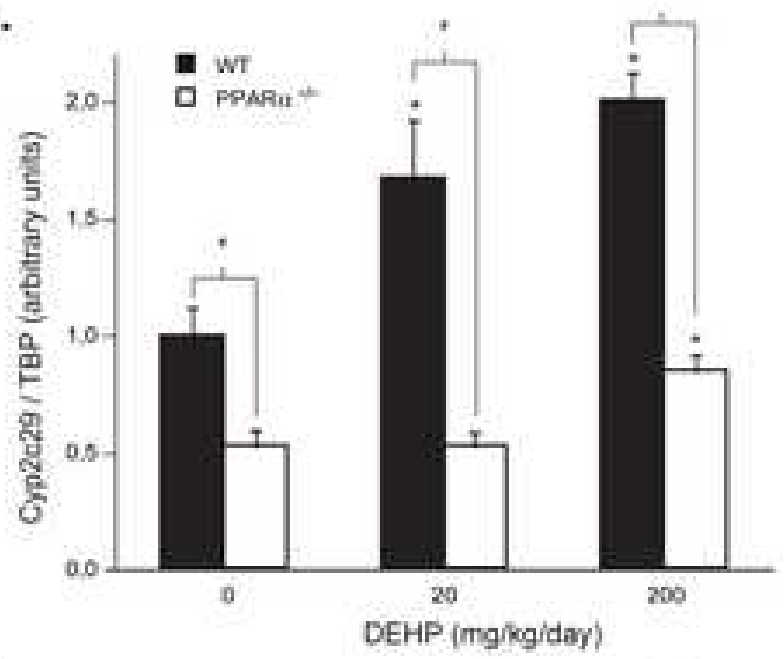

D.

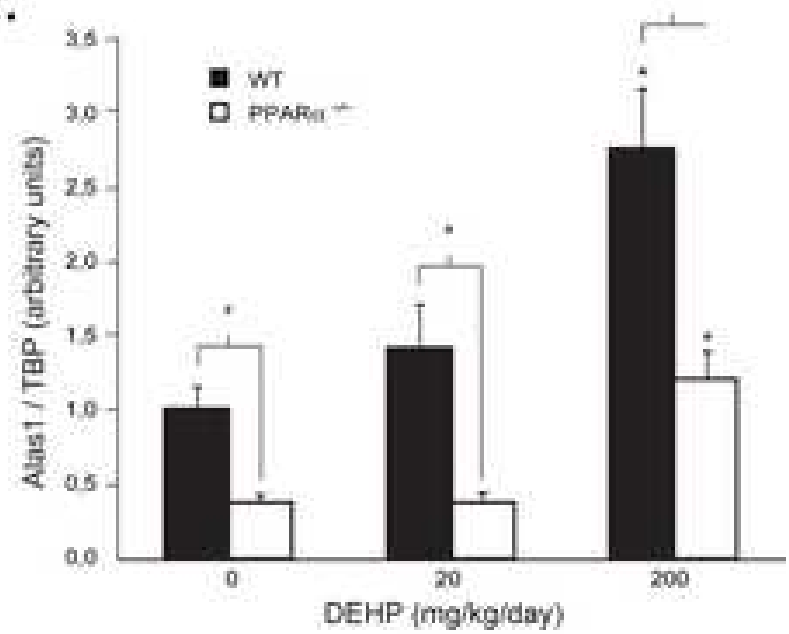

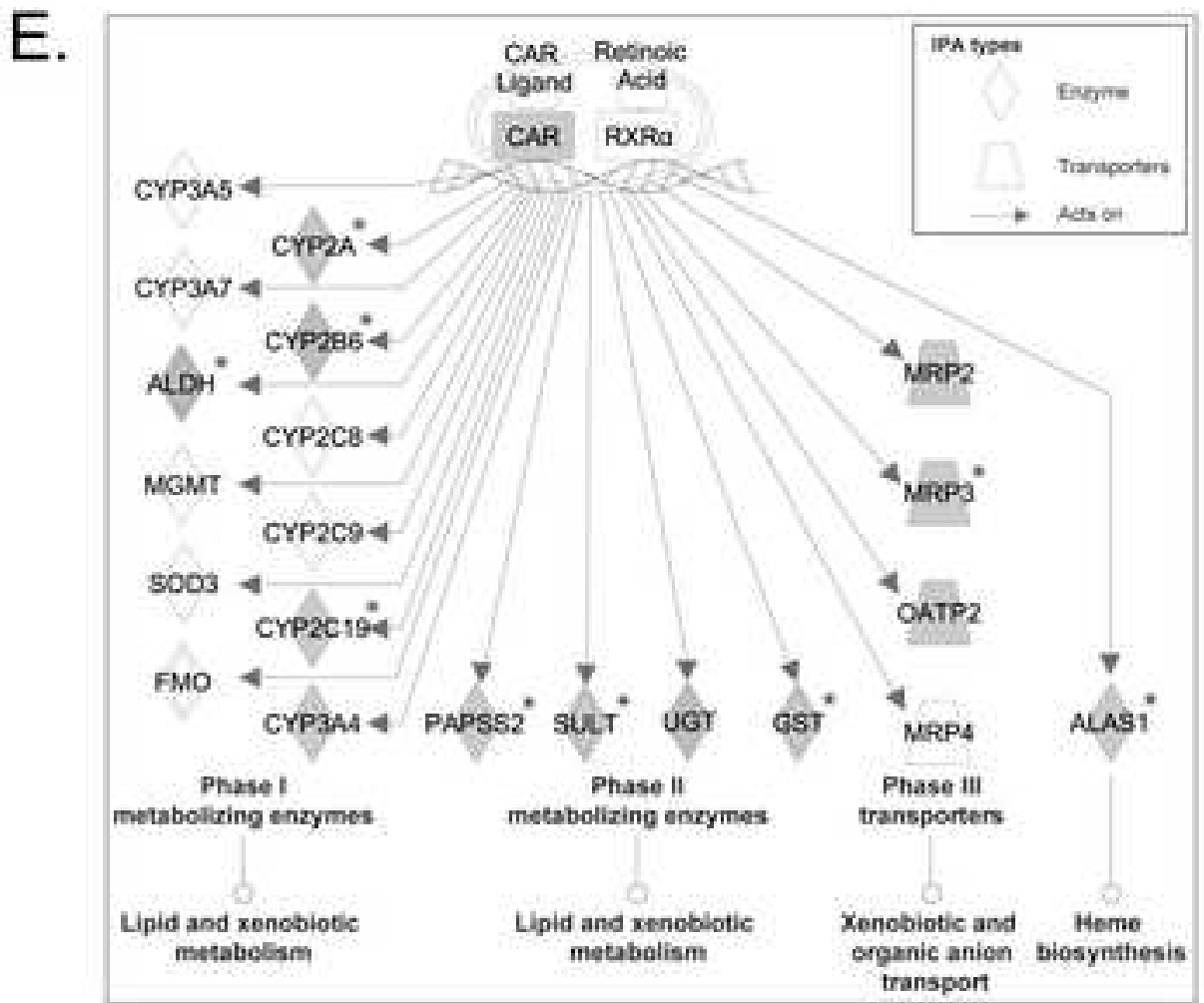


Figure 4.

A.

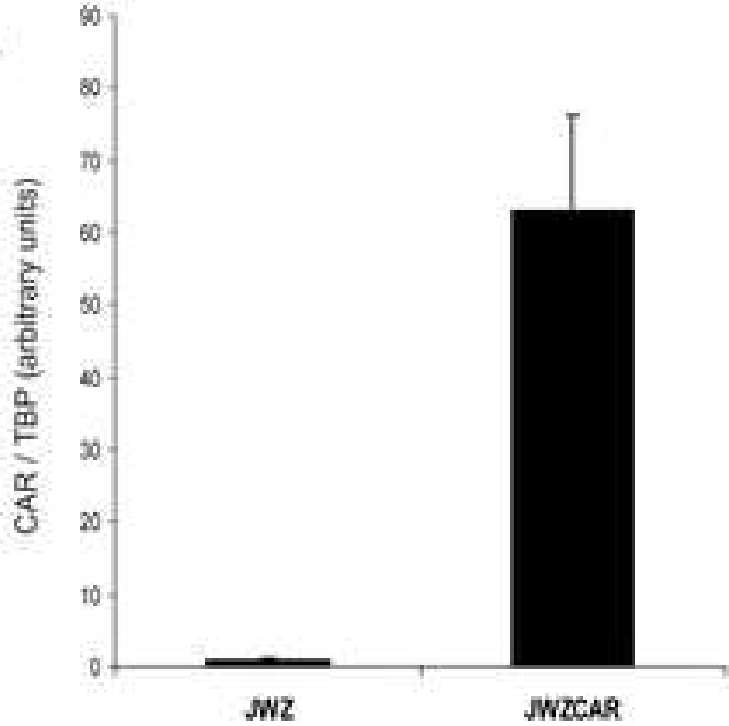

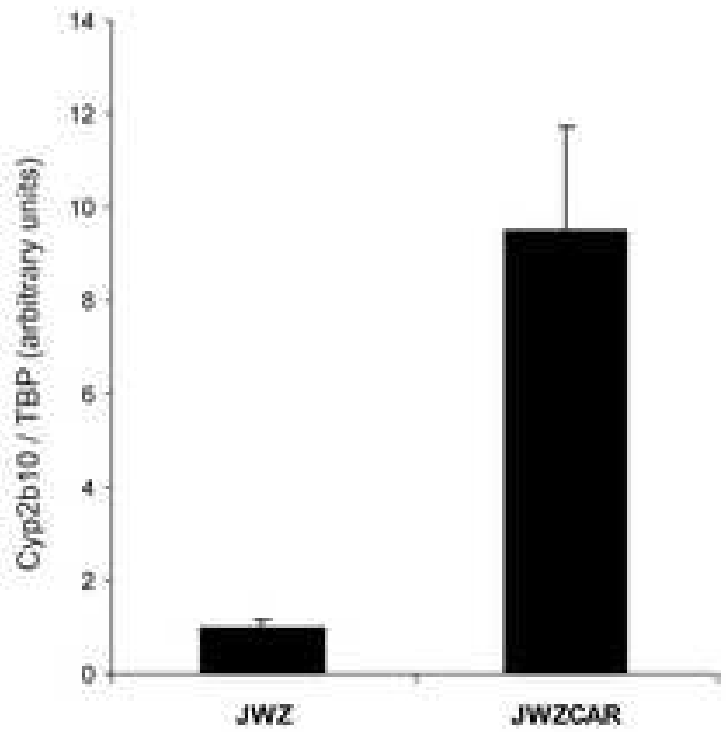

B.

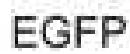

EGFP-CAR

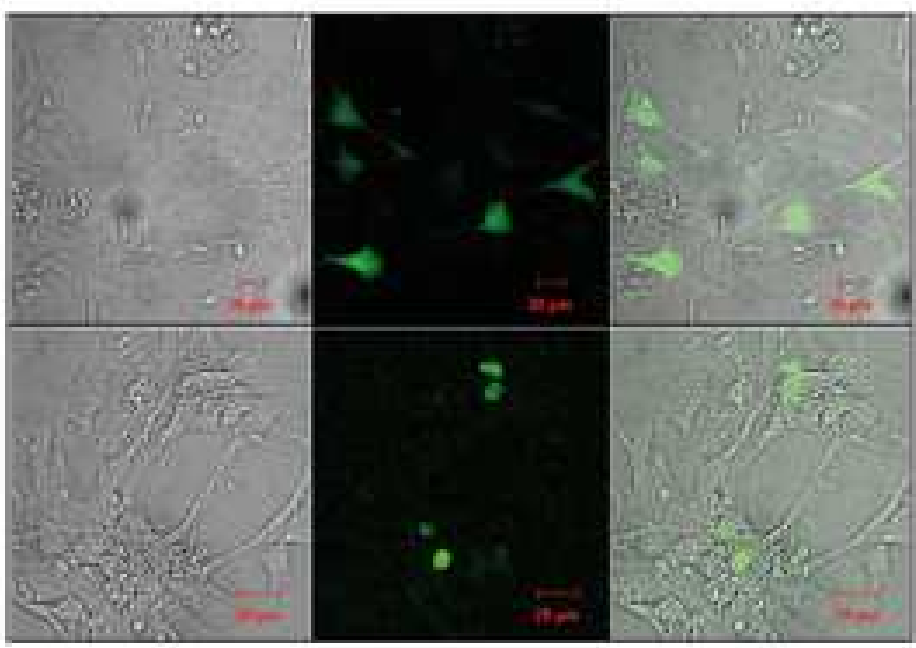

C.
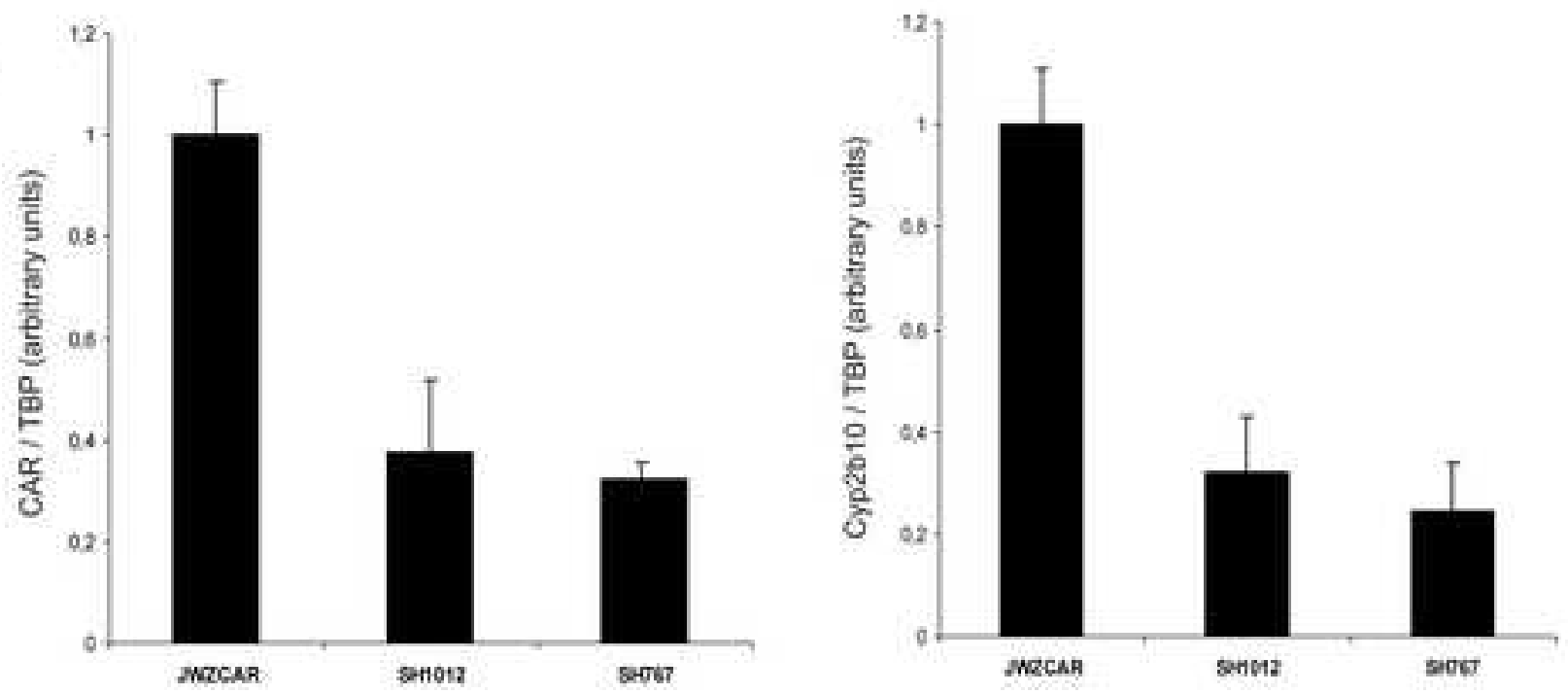

rage 28 of 31 
Figure 5.

A.

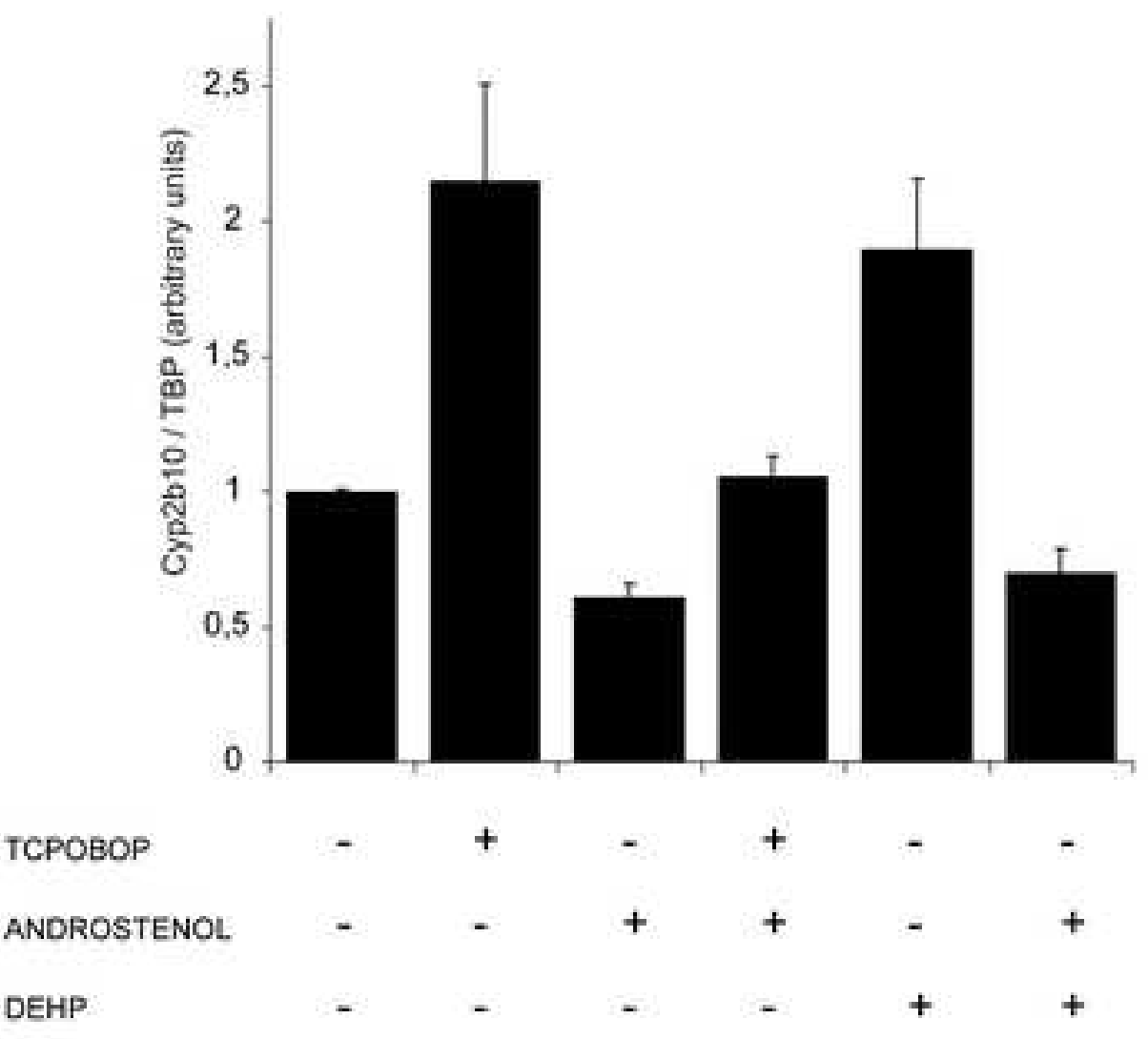

B.

C.

SH1012

SH767
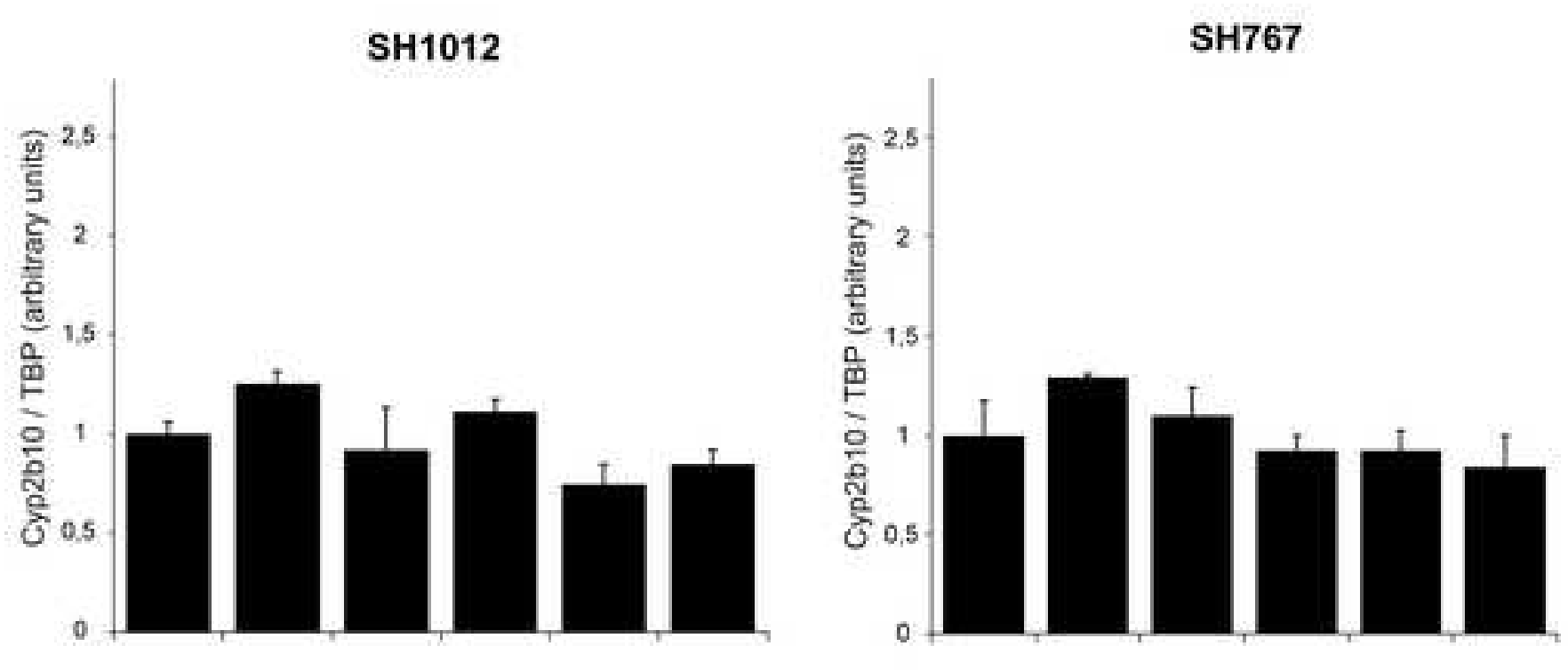

TCPOBOP

ANDROSTENOL - $-\quad+\quad+\quad-\quad+$

DEHP

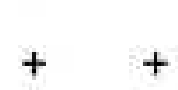

$+\quad+$

Page 29 of 31

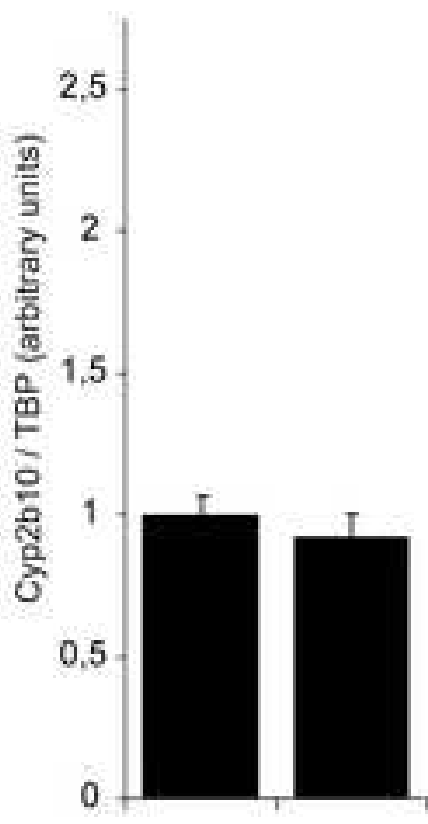

Ctrl MEHP 
Figure 6.

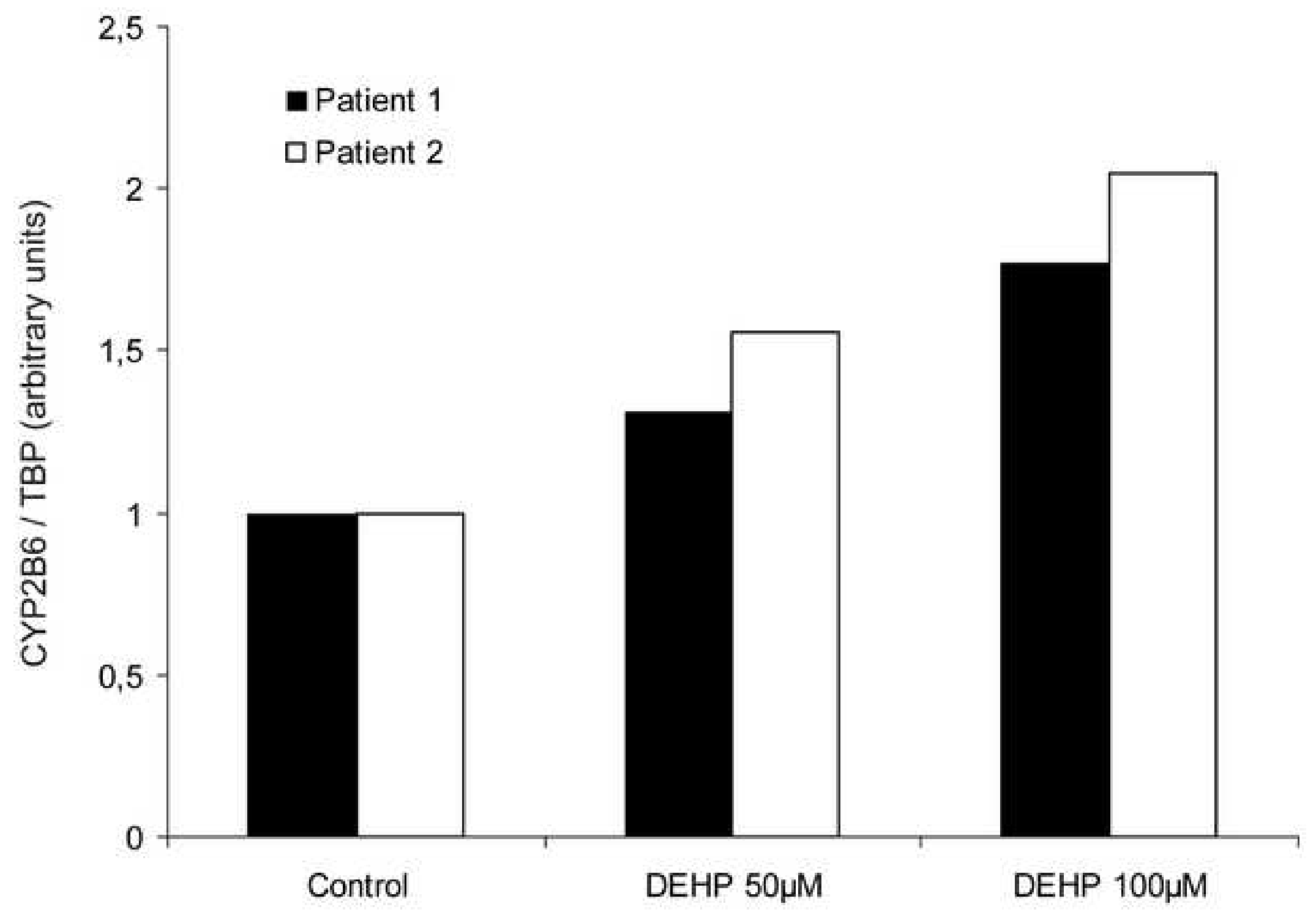

Page 30 of 31 


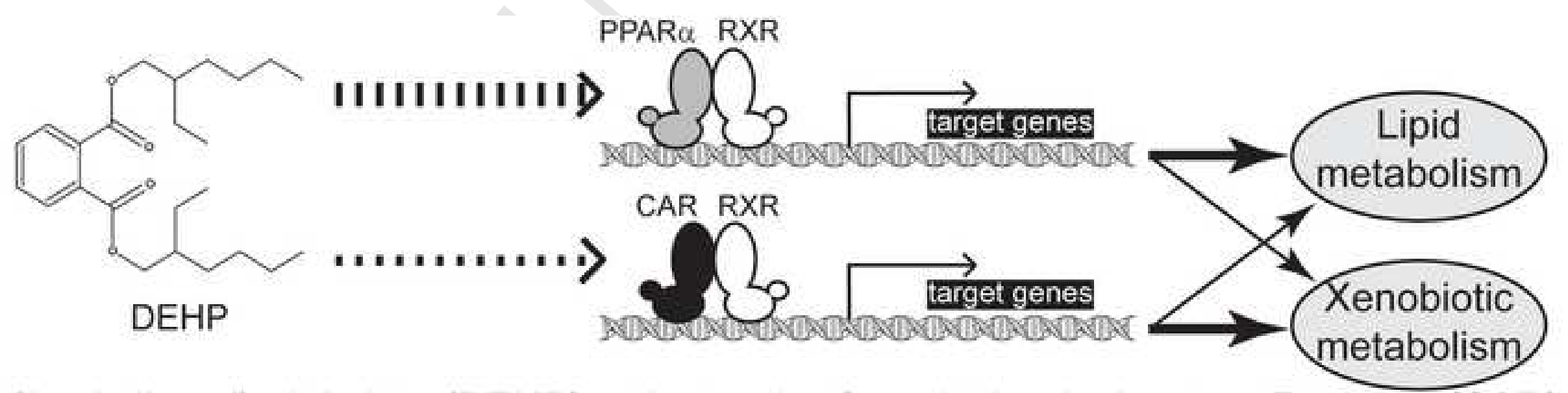

Di-(2-ethylhexyl)-phthalate (DEHP) activates the Constitutive Androstane Receptor (CAR): a novel PPAR $\alpha$ independant pathway sensitive to phthalates. 